\title{
Implementation of a Common Content-Based Assessment for Experiment- Centric Pedagogy in Three HBCU ECE Programs
}

\author{
Prof. Kenneth A. Connor, Rensselaer Polytechnic Institute
}

Kenneth Connor is a professor in the Department of Electrical, Computer, and Systems Engineering (ECSE) where he teaches courses on electromagnetics, electronics and instrumentation, plasma physics, electric power, and general engineering. His research involves plasma physics, electromagnetics, photonics, biomedical sensors, engineering education, diversity in the engineering workforce, and technology enhanced learning. He learned problem solving from his father (ran a gray iron foundry), his mother (a nurse) and grandparents (dairy farmers). He has had the great good fortune to always work with amazing people, most recently professors teaching circuits and electronics from 13 HBCU ECE programs and the faculty, staff and students of the SMART LIGHTING ERC, where he is Education Director. He was ECSE Department Head from 2001 to 2008 and served on the board of the ECE Department Heads Association from 2003 to 2008 .

\section{Dr. Yacob Astatke, Morgan State University}

Dr. Yacob Astatke completed both his Doctor of Engineering and B.S.E.E. degrees from Morgan State University (MSU) and his M.S.E.E. from Johns Hopkins University. He has been a full time faculty member in the Electrical and Computer Engineering (ECE) department at MSU since August 1994 and currently serves as the Interim Associate Dean for Undergraduate Studies in the School of Engineering. Dr. Astatke is the winner of the 2013 American Society for Engineering Education (ASEE) "National Outstanding Teaching Award," and the 2012 ASEE Mid-Atlantic Region "Distinguished Teacher" Award. He teaches courses in both analog and digital electronic circuit design and instrumentation, with a focus on wireless communication. He has more than 15 years experience in the development and delivery of synchronous and asynchronous web-based course supplements for electrical engineering courses. Dr. Astatke played a leading role in the development and implementation of the first completely online undergraduate ECE program in the State of Maryland. He has published over 50 papers and presented his research work at regional, national and international conferences. He also runs several exciting summer camps geared towards middle school, high school, and community college students to expose and increase their interest in pursuing Science Technology Engineering and Mathematics (STEM) fields. Dr. Astatke travels to Ethiopia every summer to provide training and guest lectures related to the use of the mobile laboratory technology and pedagogy to enhance the ECE curriculum at five different universities.

\section{Dr. Dianna Newman, University at Albany-SUNY}

Dr. Dianna Newman is a research professor in the Evaluation Consortium at the University at Albany/SUNY. Her major areas of study are program evaluation with an emphasis in STEM related programs. She has numerous chapters, articles, and papers on technology-supported teaching and learning as well as systems-change stages pertaining to technology adoption.

Kathy Ann Gullie Ph.D., University at Albany/SUNY

Dr. Kathy Gullie has extensive experience as a Senior Evaluator and Research Associate through the Evaluation Consortium at the University at Albany/SUNY. She is currently the principal investigator in several educational grants including an NSF engineering grant supporting Historically Black University and Colleges; "Building Learning Communities to Improve Student Achievement: Albany City School District", and "Educational Leadership Program Enhancement Project at Syracuse University" Teacher Leadership Quality Program. She is also the PI on both "Syracuse City School District Title II B Mathematics and Science Partnership: Science Project and Mathematics MSP Grant initiatives.

\section{Dr. Mohamed F. Chouikha, Howard University}

Dr. Mohamed Chouikha is a professor and chair of the Department of Electrical and Computer Engineering at Howard University. He received his M.S. and Ph.D. in Electrical Engineering from the University 
of Colorado-Boulder. Dr. Chouikha's research interests include machine learning, intelligent control, and multimedia signal processing communications for secure networks, among other areas. He also focuses on enhancing recruitment and retention of underrepresented minorities in the STEM areas in general, engineering in particular.

\section{Dr. John Kelly, North Carolina A\&T State University}

Dr. John C. Kelly, Jr. is chair and associate professor in the Department of Electrical and Computer Engineering at North Carolina A\&T State University. He received his Ph.D. in Electrical Engineering from the University of Delaware. Dr. Kelly's research interests include hardware security in cyber-physical systems and embedded systems security. He also contributes to research on engineering education, enhanced retention of underrepresented minorities in engineering, and hands-on learning techniques.

\section{Dr. Abdelnasser A. Eldek, Jackson State University}

Dr. Abdelnasser A. Eldek obtained his Ph.D. in Electrical Engineering in 2004 from the University of Mississippi. Currently, he is Professor with the Department of Electrical and Computer Engineering at Jackson State University. His main research areas include Applied Electromagnetics, Antennas, Phased Arrays, RF/Microwave Circuits, Metamaterial, and Numerical Methods.

\section{Dr. Otsebele E. Nare, Hampton University}

Otsebele Nare is an Associate Professor of Electrical Engineering at Hampton University, VA. He received his electrical engineering doctorate from Morgan State University, Baltimore, MD, in 2005. His research interests include System_Level Synthesis Techniques and K-16 Integrative STEM education. 


\begin{abstract}
This paper presents findings from a new phase of a multi-year project that is initiating technology supported experiment centric approaches to learning in electrical and computer engineering courses at 13 Historically Black Colleges and Universities. During this new phase, a series of content surveys were developed and piloted to document immediate student gains in knowledge. Three sites implemented similar modules of instruction and, utilizing variations of experimental studies and similar content quizzes, investigated evidence based student learning of module content. Data were collected over the course of one academic semester (Spring 2016); all instructors were experienced in content, use of the Analog Discovery personal instrumentation, and experiential learning. In this paper, the authors present the validated modules which integrated the Experiment Centric Pedagogy (ECP) into selected experiential teaching and learning settings, their use in the specific site studies, and student outcomes. The first site used a modified (non-random) Solomon Four experimental design with half the students using the ECP approach and half not receiving this support. Within each of these groups half the students participated in a post-test only design while half participated in a pre-post-test design (to rule out impact of pre-test). At the second site, a post-hoc, causal comparative design was implemented; students from two different classes with different instructors taught the content; one class of students utilized ECP, the other class did not. At this site, a second study, pre-post only, was conducted within the experimental class to investigate carryover in learning. At the third site, a pre-test post-test pre-experimental design was used to document standard gains in learning when experimental approaches were implemented. Findings from these studies, as well as others from previous implementation, will be discussed as well as replicability and transferability of these studies to other sites and their implications for future use. The study will conclude with suggestions for refined studies and the need for continued documentations of student and faculty outcomes.
\end{abstract}

\title{
Introduction
}

In 2013, Howard University, in collaboration with Alabama A\&M University, Florida A\&M University, Hampton University, Jackson State University, Morgan State University, Norfolk State University, North Carolina A\&T State University, Prairie View A\&M University, Southern University, Tennessee State University, Tuskegee University, and University of Maryland Eastern Shore, received funding for an National Science foundation (NSF) grant entitled, "Experiment Centric Based Engineering Curriculum for HBCUs". The project advances a process which will create a sustainable "HBCU Engineering Network" that is focused on the development, implementation, and expansion of an Experiment centric-based instructional pedagogy in engineering curricula used in these HBCUs. 
The goal of the project is to increase the number of highly qualified and prepared African American engineers, and all students, to have a better understanding of technology and its role in STEM education and the policy associated with it. Another key goal for the grant is to promote wide spread dissemination of portable hands-on mobile devices through proactive collaboration between educational institutions and industry partners. Collaborating partners are each using portable hands-on hardware coupled with a model of pedagogy (i.e., blended learning - a combination of lecture and hands-on activities in class; traditional - hands-on activities are completed outside of class time; etc.) to provide instruction in their courses.

The purpose of the external evaluation is to:

- Document the development of instructional infrastructure that will foster the use of handheld devices including equipment, materials, and staff knowledge;

- Identify instructional use including the process and immediate outcomes;

- Identify long-term outcomes including sustainability, the process of acquiring sustainability that might be replicable, and any long-term outcomes; and

- Disseminate information on outcomes and lessons learned.

The following report documents student cognitive outcomes resulting from selected pilot studies that were conducted during the 2015-16 academic year. These studies were unique from prior and ongoing studies whose focus is on documenting pre-requisites to learning, on-going learning patterns, and self-reported learning outcomes. The focus of the current studies is on assessed learning, using project developed instruments that document gains in knowledge related to Voltage Division and Thevenin's Theorem content.

\section{Content/Instrumentation}

As part of project work, members of the leadership team selected two discipline related topics, Voltage Division and Thevenin's Theorem, as circuit content found in at least one, if not multiple courses, within each of the 13 collaborating institutions. The students consisted of undergraduates enrolled in engineering courses; the unique audience represents students enrolled in HBCU colleges. The content or setting of use reflected "Introduction to Electrical Engineering" (second semester freshmen level course), and other early electrical engineering courses. The selection of the two topics was made using the following process. A series of questions used in introductory level ECE courses was presented to representatives from all 13 institutions at both in person and online meetings. The group collectively reduced the question set to the key questions that could be used at all schools. The results of this process are consistent with similar approaches taken in other projects [Streveler et al]. Note that the two concepts are closely related in that Thevenin's Theorem can be developed starting from Voltage Dividers. Both are very important with Voltage Dividers usually easily understood by ECE students and Thevenin's Theorem generally not.

Following selection of the topics, two multi-item content surveys were developed to assess gains in student knowledge. The Voltage Division survey consisted of three circuit related questions that assessed the ability of students to show an understanding of Ohm's Law and how it can be used to find voltages in electric circuits without the need to find the current. The first problem (fig. 1) was much simpler than the other two problems because the students could easily and 
directly find the required voltages across the two resistors by entering all the given variables in the circuit. The second and third problems (fig. 2) were more advanced because they required the students to have a deeper understanding of Ohm's Law and Voltage Division in order to find the unknown variables by writing multiple equations and combining them to compute the final answer. For example, in Figure 1(b) the students have to determine both the battery voltage $\mathrm{V}_{\text {batt }}$ and its internal resistance $\mathrm{R}_{\text {batt }}$ given two sets of equations showing the relationships between $\mathrm{R}_{\text {load }}$, and $\mathrm{V}_{\text {out }}$.
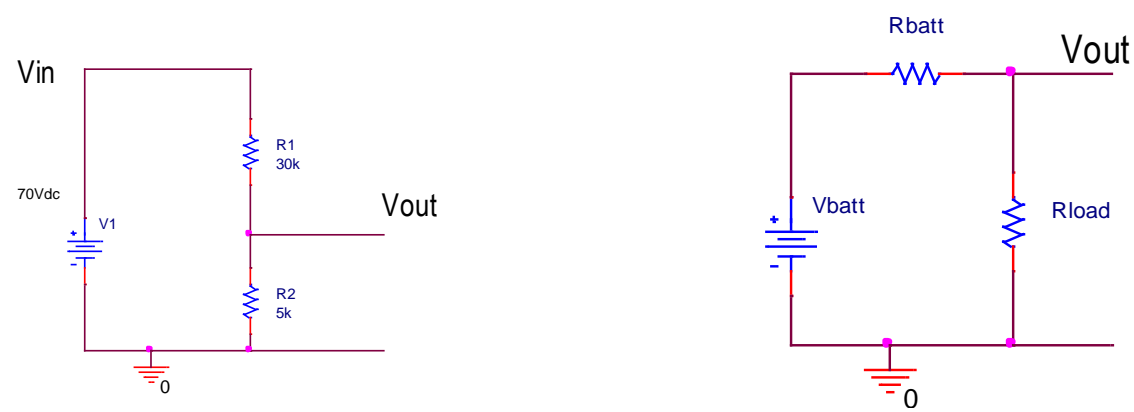

Figure 1: (a) simple Volt Div. Problem; (b) advanced Volt Div. Problem

The Thevenin's Theorem survey also presented three items that assessed the students' ability to understand and be able to find the Thevenin voltage $\mathrm{V}_{\mathrm{TH}}$ and resistance $\mathrm{R}_{\mathrm{TH}}$ for two types of circuits: the first one with a single voltage source and the second one with two voltage sources. Validity of the items' content, presentation and scoring was obtained through review by the larger leadership team; these expert reviewers included experienced ECE faculty and department heads as well as two external educational evaluators who assessed language and presentation. (See Appendix A for a sample instrument.)

\section{Research Questions}

Faculty at three of the thirteen institutions (Morgan State, Jackson State University, and Hampton University) opted to pilot content surveys as part of their integrated evaluation of outcomes of experiment centric pedagogy supported by Analog Discovery (AD) Boards. Data from each site were used to address at least two of the following cross-site research questions:

1. Do students who receive experiment centric pedagogy, supported by AD Boards, make greater gains than those who participated in traditional pedagogy?

2. Do students who received additional experiment centric pedagogy, supported by AD Boards, make greater gains than those who participated only in traditional pedagogy, when the initial knowledge base is different?

3. Do students who receive experiment centric pedagogy, supported by the AD Boards, gain in knowledge? Does evidence of this gain occur across different sites/instructors, types of classes, and varying uses?

4. Do these pilot studies contribute to knowledge of external experimental validity (mortality and instrumentation) that should be controlled in future studies? 


\section{Site Procedures}

Three HBCU sites (Morgan State, Jackson, and Hampton) implemented similar modules of instruction and, utilizing variations of experimental studies and similar content quizzes, investigated evidence-based student learning of module content. Selection of Voltage Division and Thevenin's Theorem and/or its implementation differed by institution. Following is a brief description of use at the three site and the questions their data address.

\section{Morgan State}

Project use at Morgan State was addressed through two courses: Introduction to Electrical Engineering" EEGR-105 and Circuits II (EEGR202). The following is a brief description of use in setting. Provided in Appendix B is an in-depth overview of use in the Introduction course.

Introductory Class: An experimental pilot of ECP/ADB with an emphasis on students' content growth was conducted in two sections of "Introduction to Electrical Engineering" (EEGR-105) a 3 credit freshmen level course required for all ECE majors. The sections are taught in classrooms equipped with benchtop instrumentation that can be used to conduct regular laboratory experiments for courses such as Electric Circuits. The instructors in both sections cover introductory circuit theory (i.e., series and parallel resistance combinations, Ohm's Law, and Kirchoff's voltage and current laws) and required students to conduct hands on sessions using the regular laboratory instrumentation in groups of 2 to 3. Students in one section (control) only used the regular laboratory equipment, whereas students in the other section (treatment) used the portable laboratory instrumentation (such as the Analog Discovery Board) inside and outside the classroom in addition to the regular laboratory equipment. The module under study addressed the Voltage Divider. Prior to instruction to the topic, students in both sessions were assessed via the project developed pre-test which yielded two dependent variables based on responses to Circuit 1 and Circuit 3. After completion of the treatment or control instructional modules, students were then given the post test on similar material. These data yielded a pre-test post-test treatment/control design with pre-existing groups (control $n=21$; treatment $n=24$ ). Findings were used to address Question 1. Students in the treatment group also received instruction and pre/post testing on Circuit 2; responses to this question were used to address question 3 (gains in knowledge).

Circuit Class: Students enrolled in a sophomore level Circuit 2 class (ENGR202) served as participants in studies that were used to test for overall student gains at Morgan State). Content assessed included both Voltage Division and Thevenin's Theorem. In this class, all students participated in experiment centric hands-on learning supported by the Analog Discovery Board. The resulting dependent variables reflect gains in three sub scores on the Voltage Division quiz (as well as the total score) and two sub scores on the Thevenin's Theorem quiz (as well as the total score) These data allowed for formation of pre-test, treatment, post-test design using a preexisting group that addressed Question 3. Additional data from this class also was used to contribute questions relating to Question 4A Mortality and Question 4B Instrumentation. 


\section{Hampton University}

The project use at Hampton University was addressed through one course: DC Electric Circuit Analysis (EGR 218) and included a total of 9 matched-data subjects. EGR 218 is a sophomore level course serving electrical, computer, and chemical engineering students as well as music recording technology students. Students were introduced to the use of the Analog Discovery Board for hands on learning activities as part of this lecture course. AD board activities were mainly assigned as out of class project activities after the concepts had been covered in class including assignment of homework problems. Every other week, time was allocated during the lecture sessions to assist students with $\mathrm{AD}$ board examples and other circuit analysis tools. The effectiveness of the approach of using hands on activities was measured through the use of standard questions. As an example, two Thevenin's Theorem concept problems were given to the students as a quiz immediately after completing nodal and mesh analysis lessons in class. A version of the pre-quiz for Thevenin's Theorem was administered prior to covering any of the circuit theorems/concepts (superposition, source transformation, Thevenin, or Norton) and the solutions were never given or discussed with the students. After the completion of the circuit theorems in class and the assignment of $\mathrm{AD}$ board project on the theorem, the same standard questions were administered again with different resistor values and power sources. Grading was done after the completion of each quiz and the students received extra credit to their quiz grade for the course. This pilot resulted in a pre-test post-test pre-experimental design, documenting standard gains in learning when experimental approaches were implemented. Three dependent variables were used for the analysis, Item 1(circuit 1) Item 2 (circuit 2) and Quiz total (sum of items (circuits) 1 and two, Findings from this pilot study contributed to Question 3, Question 4A (Mortality), and Question 4B (Instrumentation)

\section{Jackson State University}

The project at Jackson State was addressed through one course: Circuits Theory, CPE 220.This course serves as a required course for Electrical Engineering (EE), Computer Engineering (CPE) and Civil Engineering (CIV) students. The basic course is lecture in format, EE and CPE students are required to participate in an additional lab (Circuit Laboratory ENL 220). The content selected for use in this site was Thevenin's Theorem. This topic is covered by the instructor during lecture/traditional class through examples, hands on calculation, and homework. Students participating in the lab receive additional instruction and practice on the topic. For the pilot, these students were given the ADB and asked to build the circuit, and measure Thevenin's voltage and resistance as well as Norton's current using the ADB. Documentation of the impact of use supported a non-random Solomon Four Experimental Design that yielded four naturally occurring comparative groups. Two of these groups received the pre-test on Thevenin's Theorem; these included students who would subsequently be part of the control group (theory class only) and students who would receive treatment (theory class and lab with ADB). Two additional groups were also formed: control students who did not receive the pre-test and treatment students who did not receive the pre-test. After completion of the theory/lecture component and, for those assigned to lab/ADB, the post test was given to all students resulting in four sets of post test data: class with pre and post (45), class with post only (19), class and lab with pre and post (30), class and lab with post only (9). This pilot study contributed to Question 2 and Question 4B Instrumentation. 


\section{Results}

The following tables outline the results of responses to four research questions addressed through content surveys as part of an integrated evaluation of outcomes of experiment centric pedagogy supported by AD Boards. Data from each site was used to address cross-site research questions. Each table summarizes the findings for one of the four questions, offering a summary of site specific contributions to the questions, statistical inferential results, an interpretation of those results, and a summary for the general question. 


\begin{tabular}{|c|c|c|c|c|c|c|c|c|c|c|}
\hline \multicolumn{11}{|c|}{$\begin{array}{l}\text { Question 1: Do students who receive experiment centric pedagogy, supported by ADBs make greater gains than those who receive traditional } \\
\text { learning? Intact Group Pre-test, Post-test Treatment Control Group Design }\end{array}$} \\
\hline Study & Institution & Students & $\begin{array}{l}\text { Module/ } \\
\text { Content }\end{array}$ & Treatment & Variable & $\begin{array}{l}\text { Pre } \\
\text { Mean } \\
\text { (s.d.) }\end{array}$ & $\begin{array}{l}\text { Post } \\
\text { Mean } \\
\text { (s.d.) }\end{array}$ & $\begin{array}{l}\text { Test } \\
(\mathrm{df}=1,43)\end{array}$ & Results & Interpretation \\
\hline \multirow[t]{3}{*}{1} & Morgan & $\begin{array}{l}\text { EEGR105 } \\
\text { Intro Eng. } \\
n(t)=24 \\
n(c)=21\end{array}$ & $\begin{array}{l}\text { Voltage } \\
\text { Divider }\end{array}$ & $\begin{array}{l}\text { Two sections, } \\
\text { freshman class, } \\
\text { treatment received } \\
\text { ECP/ADB in lab } \\
\text { setting, took ABD } \\
\text { home, control did not } \\
\text { have ABD }\end{array}$ & Circuit 1 & $\begin{aligned} \mathrm{T} & =3.04 \\
& (2.06) \\
\mathrm{C}= & 1.88 \\
& (1.37)\end{aligned}$ & $\begin{aligned} \mathrm{T}= & 6.75 \\
& (2.43) \\
\mathrm{C}= & 4.10 \\
& (1.69)\end{aligned}$ & $\begin{array}{l}F(t / c)=20.92 ; p<.001 \\
F(\text { time })=52.75 ; p<.001 \\
F(t X t)=3.36 ; p=.074\end{array}$ & $\begin{array}{l}\text { Significant } \\
\text { Significant } \\
\text { Not } \\
\text { Significant }\end{array}$ & $\begin{array}{l}\text { Both treatment and } \\
\text { control gained; while the } \\
\text { gains were not } \\
\text { significantly different, } \\
\text { the treatment group } \\
\text { tended to gain more than } \\
\text { the control group. }\end{array}$ \\
\hline & & & & & Circuit 2 & $\begin{array}{r}\mathrm{T}=0.00 \\
(0.00) \\
\mathrm{C}=0.43 \\
(1.96)\end{array}$ & $\begin{array}{c}\mathrm{T}=5.40 \\
(3.80) \\
\mathrm{C}=1.95 \\
(2.67)\end{array}$ & $\begin{array}{l}F(t / c)=7.41 ; p<.001 \\
F(\text { time })=44.6 ; p<.001 \\
F(t X t)=13.97 ; p<.001\end{array}$ & $\begin{array}{l}\text { Significant } \\
\text { Significant } \\
\text { Significant }\end{array}$ & $\begin{array}{l}\text { Both treatment and } \\
\text { control started with } \\
\text { limited assessed } \\
\text { knowledge, both made } \\
\text { gains but treatment } \\
\text { group made significantly } \\
\text { greater gains } \\
\text { (approximately } 4 \\
\text { additional points). }\end{array}$ \\
\hline & & & & & Circuit 3 & $\begin{array}{r}\mathrm{T}=3.04 \\
(2.06) \\
\mathrm{C}=2.31 \\
(2.51)\end{array}$ & $\begin{array}{c}\mathrm{T}=12.15 \\
(5.21) \\
\mathrm{C}=6.05 \\
(3.17)\end{array}$ & $\begin{array}{l}F(t / c)=18.08 ; p<.001 \\
F(\text { time })=93.08 ; p<.001 \\
F(t X t)=16.25 ; p<.001\end{array}$ & $\begin{array}{l}\text { Significant } \\
\text { Significant } \\
\text { Significant }\end{array}$ & $\begin{array}{l}\text { Starting with some } \\
\text { initial knowledge, both } \\
\text { treatment and control } \\
\text { groups gained assessed } \\
\text { knowledge but the } \\
\text { treatment group made } \\
\text { significantly greater } \\
\text { gains than the control } \\
\text { group (approximately } 5 \\
\text { additional points). }\end{array}$ \\
\hline
\end{tabular}

Overall Conclusion: Students in introductory engineering classes who received ECP supported by the ADB made significantly greater gains than those who received traditional instructional practices. The instructor in this setting was highly experienced in use of both the ECP and the ADB. The finding of this study, though limited to only one setting, supports continued documentation across different settings, instructors, and content. 


\begin{tabular}{|c|c|c|c|c|c|c|c|c|c|c|c|}
\hline \multicolumn{12}{|c|}{$\begin{array}{l}\text { Question 2: Do students who received additional experiment centric pedagogy, supported by AD Boards, make greater gains than those who } \\
\text { participated only in traditional pedagogy, when the initial knowledge base is different? } \\
\text { Four intact groups, two receive treatment, two serve as control, one of each setting received the pretest (non-random Solomon Four design) }\end{array}$} \\
\hline Study & Institution & Students & $\begin{array}{l}\text { Module/ } \\
\text { Content }\end{array}$ & Treatment & $\begin{array}{l}\text { Variable } \\
100 \mathrm{pts}\end{array}$ & $\begin{array}{l}\text { Pre } \\
\text { Mean } \\
\text { (s.d.) }\end{array}$ & $\begin{array}{l}\text { Post } \\
\text { Mean } \\
\text { (s.d.) }\end{array}$ & $\begin{array}{l}\text { Average } \\
\text { Difference } \\
\text { post-pre }\end{array}$ & Test & Results & Interpretation \\
\hline \multirow[t]{5}{*}{2} & Jackson & EN220 & Thev & Page 6, App C & & & & & & & \\
\hline & \multicolumn{4}{|c|}{$\begin{array}{l}\text { Step One: Are the gains equivalent for those who } \\
\text { received both treatment and control? } \\
\text { Treatment } \mathrm{n}-22 \\
\text { Control } \mathrm{n}=12\end{array}$} & Total & $\begin{array}{l}t=11.25 \\
(19.27) \\
c=8.96 \\
(15.50)\end{array}$ & $\begin{array}{l}\mathrm{t}=60.00 \\
(36.08) \\
\mathrm{c}=58.44 \\
(34.07)\end{array}$ & $\begin{array}{l}\mathrm{T}=48.75 \\
\mathrm{C}=49.48\end{array}$ & $\begin{array}{l}\mathrm{F}(\mathrm{t} / \mathrm{c})=0.85 \\
\mathrm{~F}(\mathrm{time})=72.22 \\
\mathrm{~F}(\mathrm{txt})=0.00\end{array}$ & $\begin{array}{l}\text { Not Signif } \\
\text { Significant } \\
\text { Not Signif }\end{array}$ & $\begin{array}{l}\text { All students made } \\
\text { approximately } 49 \text { points } \\
\text { gain. There was no } \\
\text { difference between } \\
\text { treatment and control }\end{array}$ \\
\hline & \multicolumn{4}{|c|}{$\begin{array}{l}\text { Step Two A: Can treatment groups be combined? Are } \\
\text { their post-tests different due to instrumentation? } \\
\text { With pre } n=22 \\
\text { With no pre } n=14\end{array}$} & Total & \multicolumn{2}{|c|}{$\begin{array}{r}\text { Treatment } \mathrm{w} \\
\text { pre }=60.00 \\
(36,08) \\
\text { Treatment w no } \\
\text { pre }=61.79 \\
(33.17)\end{array}$} & & $\begin{array}{l}\text { Ind } t=0.88 \\
d f=34 \\
P>.10\end{array}$ & $\begin{array}{l}\text { Not } \\
\text { significant }\end{array}$ & $\begin{array}{l}\text { There was no difference } \\
\text { in post test scores for } \\
\text { treatment groups; the } \\
\text { pre-test did not influence } \\
\text { post test results. The two } \\
\text { treatment groups can be } \\
\text { combined. }\end{array}$ \\
\hline & \multicolumn{4}{|c|}{$\begin{array}{l}\text { Step Two B: Can control groups be combined? Are } \\
\text { their post-tests different due to instrumentation? } \\
\text { With pre } n=12 \\
\text { With no pre } n=18\end{array}$} & Total & \multicolumn{2}{|c|}{$\begin{aligned} \text { Control w pre } & 58.44 \\
& (34.07) \\
\text { Control no pre } & =57.29 \\
& (26.30)\end{aligned}$} & & $\begin{array}{l}\text { Ind } t=0.92 \\
D f=26 \\
P=>10\end{array}$ & $\begin{array}{l}\text { Not } \\
\text { significant }\end{array}$ & $\begin{array}{l}\text { There was no difference } \\
\text { in post test scores } \\
\text { between control groups; } \\
\text { the pre-test did not } \\
\text { influence post test } \\
\text { results. The two control } \\
\text { groups can be combined. }\end{array}$ \\
\hline & \multicolumn{4}{|c|}{$\begin{array}{l}\text { Step Three: Since instrumentation is not an issues, are } \\
\text { the post-scores for those receiving treatment } \\
\text { different than those in the control setting? } \\
\text { Treatment } n=36 \\
\text { Control } n=30\end{array}$} & Total & \multicolumn{2}{|c|}{ 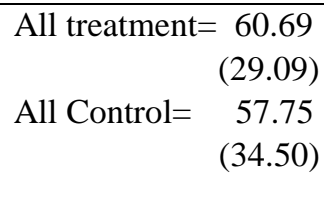 } & & $\begin{array}{l}\text { Ind } t=0.37 \\
\mathrm{Df}=64 \\
\mathrm{P}=>.10\end{array}$ & $\begin{array}{l}\text { Not } \\
\text { significant }\end{array}$ & $\begin{array}{l}\text { There was no difference } \\
\text { between treatment and } \\
\text { control outcomes on } \\
\text { assessed content. }\end{array}$ \\
\hline
\end{tabular}

Overall conclusion: Students who received experiment centric learning, supported by the ADB, as part of their required labs did not evidence greater gains than did those students who did not receive the labs/treatment. The treatment students started with more knowledge than the control students (in the same lecture class) and maintained that lead. This finding supports the need for further studies across different majors and use in lab-separate instructional settings. Statistical power may contribute to this finding. 


\begin{tabular}{|c|c|c|c|c|c|c|c|c|c|c|c|}
\hline \multicolumn{12}{|c|}{$\begin{array}{l}\text { Question 3: Do students who receive experiment centric pedagogy, supported by the ADB, gain in content knowledge? } \\
\text { Four "One Shot Pre-test Treatment Post-test Only" studies, with intact groups [ NR: O X O]; multiple dependent variables; }\end{array}$} \\
\hline$\overline{\text { Study }}$ & Institution & Students & $\begin{array}{l}\text { Module/ } \\
\text { Content }\end{array}$ & Treatment & Variable & $\begin{array}{l}\text { Pre } \\
\text { Mean } \\
\text { (s.d.) }\end{array}$ & $\begin{array}{l}\text { Post } \\
\text { Mean } \\
\text { (s.d.) }\end{array}$ & $\begin{array}{l}\text { Average } \\
\text { Difference } \\
\text { post-pre }\end{array}$ & $\begin{array}{l}\text { Test } \\
\text { Dep t, df-17 }\end{array}$ & Results & Interpretation \\
\hline \multirow[t]{4}{*}{3} & \multirow[t]{4}{*}{ Morgan } & \multirow[t]{4}{*}{$\begin{array}{l}\text { EERG202 } \\
\mathrm{n}=18\end{array}$} & \multirow[t]{4}{*}{ Voltage } & \multirow{4}{*}{$\begin{array}{l}\text { Use of ADB within } \\
\text { studio pedagogy; } \\
\text { instructor highly } \\
\text { experienced }\end{array}$} & Circuit 1 & \begin{tabular}{|l|}
4.44 \\
$(3.40)$
\end{tabular} & $\begin{array}{l}7.47 \\
(2.27)\end{array}$ & +3.03 & $\begin{array}{l}\mathrm{t}=3.79, \mathrm{df}=17 \\
\mathrm{p}<.001\end{array}$ & Significant & \multirow{4}{*}{$\begin{array}{l}\text { Students in a circuit } \\
\text { related class } \\
\text { evidenced gains in } \\
\text { assessed knowledge. }\end{array}$} \\
\hline & & & & & Circuit 2 & \begin{tabular}{|l|}
0.78 \\
$(1.03)$
\end{tabular} & $\begin{array}{l}4.44 \\
(2.71)\end{array}$ & +3.66 & $\begin{array}{l}t=5.76 \mathrm{df}=17 \\
\mathrm{p}<.001\end{array}$ & Significant & \\
\hline & & & & & Circuit 3 & \begin{tabular}{|l|}
0.61 \\
$(0.85)$
\end{tabular} & $\begin{array}{l}6.00 \\
(4.04)\end{array}$ & +5.39 & $\begin{array}{l}\mathrm{t}=5.821 \mathrm{df}=17 \\
\mathrm{p}<.001\end{array}$ & Significant & \\
\hline & & & & & Total Score & \begin{tabular}{|l|}
5.83 \\
$(4.05)$
\end{tabular} & $\begin{array}{l}17.92 \\
(7.74)\end{array}$ & +12.09 & $\begin{array}{l}\mathrm{t}=6.89, \mathrm{df}=17 \\
\mathrm{p}<.001\end{array}$ & Significant & \\
\hline \multirow[t]{3}{*}{4} & \multirow[t]{3}{*}{ Morgan } & \multirow[t]{3}{*}{$\begin{array}{l}\text { EEGR202 } \\
\mathrm{n}=17\end{array}$} & \multirow[t]{3}{*}{ Thev } & \multirow{3}{*}{$\begin{array}{l}\text { Use of ADB within } \\
\text { studio classroom; } \\
\text { instructor highly } \\
\text { experienced }\end{array}$} & $\begin{array}{l}\text { Problem } 2 \\
\text { Circuit } 1\end{array}$ & $\begin{array}{l}2.94 \\
(1.89)\end{array}$ & $\begin{array}{l}6.74 \\
(1.95)\end{array}$ & +3.80 & $\begin{array}{l}\mathrm{t}=6.40, \mathrm{df}=18 \\
\mathrm{p}<. .001\end{array}$ & Significant & \multirow{3}{*}{$\begin{array}{l}\text { Students in a circuit } \\
\text { related class } \\
\text { evidenced gains in } \\
\text { assessed knowledge. }\end{array}$} \\
\hline & & & & & $\begin{array}{l}\text { Problem } 2 \\
\text { Circuit } 2\end{array}$ & $\begin{array}{l}0.94 \\
(2.41)\end{array}$ & $\begin{array}{l}8.00 \\
(3.00)\end{array}$ & +7.06 & $\begin{array}{l}\mathrm{t}=7.38, \mathrm{df}=18 \\
\mathrm{p}<. .001\end{array}$ & Significant & \\
\hline & & & & & $\begin{array}{l}\text { Problem } 2 \\
\text { Total }\end{array}$ & $\begin{array}{l}3.76 \\
(3.19)\end{array}$ & $\begin{array}{l}14.74 \\
(4.23)\end{array}$ & +10.98 & $\begin{array}{l}\mathrm{t}=8.37, \mathrm{df}=18 \\
\mathrm{p}<. .001\end{array}$ & Significant & \\
\hline \multirow[t]{3}{*}{5} & \multirow[t]{3}{*}{ Hampton } & \multirow[t]{3}{*}{$\begin{array}{l}\text { EGR218 } \\
\mathrm{n}=9\end{array}$} & \multirow[t]{3}{*}{ Thev } & \multirow{3}{*}{$\begin{array}{l}\text { Use of ADB within } \\
\text { lecture class } \\
\text { instructor moderate } \\
\text { experience }\end{array}$} & Item1 & $\begin{array}{l}1.33 \\
(0.66)\end{array}$ & $\begin{array}{l}6.00 \\
(1.92)\end{array}$ & +4.67 & $\begin{array}{l}t=6.89, \mathrm{df}=8 \\
\mathrm{p}<. .001\end{array}$ & Significant & \multirow{3}{*}{$\begin{array}{l}\text { Students in a circuit } \\
\text { related class } \\
\text { evidenced gains in } \\
\text { assessed knowledge. }\end{array}$} \\
\hline & & & & & Item 2 & \begin{tabular}{|l|}
1.00 \\
$(1.85)$ \\
\end{tabular} & $\begin{array}{l}5.33 \\
(1.87) \\
\end{array}$ & +4.33 & $\begin{array}{l}\mathrm{t}=6.32, \quad \mathrm{df}=8, \\
\mathrm{p}<.001\end{array}$ & Significant & \\
\hline & & & & & Total & \begin{tabular}{|l|}
2.83 \\
$(2.37)$
\end{tabular} & $\begin{array}{l}11.33 \\
(2.51)\end{array}$ & +8.50 & $\begin{array}{l}\mathrm{t}=11.23, \mathrm{df}=8 \\
\mathrm{p}<.001\end{array}$ & Significant & \\
\hline 6 & Morgan & $\begin{array}{l}\text { EEGR } 105 \\
\mathrm{n}=29\end{array}$ & Voltage & $\begin{array}{l}\text { Use of ADB within } \\
\text { studio classroom; } \\
\text { instructor highly } \\
\text { experienced }\end{array}$ & Circuit 2 & \begin{tabular}{|l}
0.08 \\
$(0.41)$
\end{tabular} & $\begin{array}{l}5.45 \\
(2.90)\end{array}$ & & $\begin{array}{l}\mathrm{t}=8.52, \mathrm{df}=23 \\
\mathrm{p}<.001\end{array}$ & Significant & $\begin{array}{l}\text { Students in an } \\
\text { introductory class } \\
\text { evidenced gains in } \\
\text { assessed knowledge. }\end{array}$ \\
\hline \multicolumn{12}{|c|}{$\begin{array}{l}\text { Overall conclusion: Students in a variety of instructional settings and classroom experiences, representing multiple content domains and instructional goals, evidenced gains } \\
\text { in knowledge when learning was supported by experiment centric pedagogy supported by the Analog Discovery Board. While it is not known if this learning is greater than that } \\
\text { which would have occurred without this experience, the results support the ability to successfully use the method across varying learning situations. When combined with } \\
\text { students self-reported and faculty reported outcomes, the outcomes support further investigation. }\end{array}$} \\
\hline
\end{tabular}




\begin{tabular}{|c|c|c|c|c|c|c|c|c|c|c|}
\hline \multicolumn{11}{|c|}{$\begin{array}{l}\text { Question 4: Secondary Question A: Do students who "drop out" (don't take post-test) differ from those who complete? } \\
\text { Is "mortality" an issue in these studies? Complete vs. No Complete Intact Groups }\end{array}$} \\
\hline Study & Institution & Subjects & Module & Treatment & Variable & $\begin{array}{l}\text { Completer } \\
\text { Pre Mean } \\
\text { (s.d.) }\end{array}$ & $\begin{array}{l}\text { Non completer } \\
\text { Pre Mean } \\
\text { (s.d) }\end{array}$ & \begin{tabular}{|l|} 
Test \\
\end{tabular} & Results & Implications \\
\hline \multirow[t]{4}{*}{7} & Morgan & EEGR202 & Voltage & $\begin{array}{l}\text { Use of ADB within } \\
\text { mobile classroom }\end{array}$ & Circuit 1 & $\begin{array}{l}4.44 \\
(3.40)\end{array}$ & $\begin{array}{l}2.69 \\
(2.38)\end{array}$ & $\begin{array}{l}\mathrm{t}=1.32 ; \mathrm{df}=24 \\
\mathrm{p}>.10\end{array}$ & $\begin{array}{l}\text { No Sig. } \\
\text { Different }\end{array}$ & \multirow{4}{*}{$\begin{array}{l}\text { Students who completed a post } \\
\text { test (e.g. participated in the } \\
\text { entire experiment) did not } \\
\text { significantly differ on pre } \\
\text { knowledge from those students } \\
\text { who took a pre but did not } \\
\text { participate in the full } \\
\text { experiment. }\end{array}$} \\
\hline & & \multicolumn{2}{|c|}{$\begin{array}{l}\mathrm{N}=18 \text { who completed } \\
\mathrm{N}=8 \text { did not complete }\end{array}$} & & Circuit 2 & $\begin{array}{l}0.78 \\
(1.00)\end{array}$ & $\begin{array}{l}0.75 \\
(0.89)\end{array}$ & $\begin{array}{l}t=0.07 ; \mathrm{df}=24 \\
\mathrm{p}>.10\end{array}$ & $\begin{array}{l}\text { No Sig. } \\
\text { Different }\end{array}$ & \\
\hline & & & & & \begin{tabular}{|l|} 
Circuit 3 \\
\end{tabular} & $\begin{array}{l}0.61 \\
(0.85)\end{array}$ & $\begin{array}{l}1.00 \\
(0.93)\end{array}$ & $\begin{array}{l}t=1.05 ; d f=24 \\
p>.10\end{array}$ & $\begin{array}{l}\text { No Sig. } \\
\text { Different }\end{array}$ & \\
\hline & & & & & \begin{tabular}{|l|} 
Total \\
\end{tabular} & $\begin{array}{l}5.83 \\
(3.42) \\
\end{array}$ & $\begin{array}{l}4.44 \\
(4.05)\end{array}$ & $\begin{array}{l}t=0.85 ; d f=24 \\
p>.10\end{array}$ & $\begin{array}{l}\text { No Sig. } \\
\text { Different }\end{array}$ & \\
\hline & & & & & & & & & & \\
\hline \multirow[t]{3}{*}{8} & Hampton & EGR218 & Thev & $\begin{array}{l}\text { Use of ADB within } \\
\text { lecture }\end{array}$ & Item 1 & $\begin{array}{l}2.50 \\
(2.12)\end{array}$ & $\begin{array}{l}6.00 \\
(1.92)\end{array}$ & $\begin{array}{l}\mathrm{t}=2.15 ; \mathrm{df}=9 \\
\mathrm{p}>.10\end{array}$ & $\begin{array}{l}\text { No Sig. } \\
\text { Different }\end{array}$ & \multirow{3}{*}{$\begin{array}{l}\text { Students who completed a post } \\
\text { test (e.g. participated in the } \\
\text { entire experiment) did not } \\
\text { significantly differ on pre } \\
\text { knowledge from those students } \\
\text { who took a pre but did not } \\
\text { participate in the full } \\
\text { experiment. }\end{array}$} \\
\hline & & \multicolumn{2}{|c|}{$\begin{array}{l}\mathrm{N}=9 \text { who completed } \\
\mathrm{N}=5 \text { did not complete }\end{array}$} & & \begin{tabular}{|l|} 
Item 2 \\
\end{tabular} & $\begin{array}{l}7.50 \\
(2.12)\end{array}$ & $\begin{array}{l}5.33 \\
(1.87)\end{array}$ & $\begin{array}{l}t=1.46 ; d f=9 \\
p>.10\end{array}$ & $\begin{array}{l}\text { No Sig. } \\
\text { Different }\end{array}$ & \\
\hline & & & & & Total & $\begin{array}{l}10.00 \\
(4.24)\end{array}$ & $\begin{array}{l}11.33 \\
(2.51)\end{array}$ & $\begin{array}{l}\mathrm{t}=0.62 ; \mathrm{df}=9 \\
\mathrm{p}>.10\end{array}$ & $\begin{array}{l}\text { No Sig. } \\
\text { Different }\end{array}$ & \\
\hline & & & & & & & & & & \\
\hline $\begin{array}{l}\text { Ove } \\
\text { be re }\end{array}$ & $=$ & 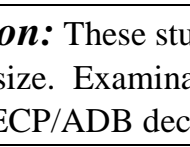 & 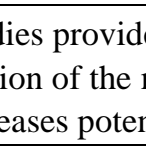 & . & . & - & 115 & to & 列 & $\begin{array}{l}\text { ignificant, these finding may } \\
\text { tional studies also should }\end{array}$ \\
\hline
\end{tabular}




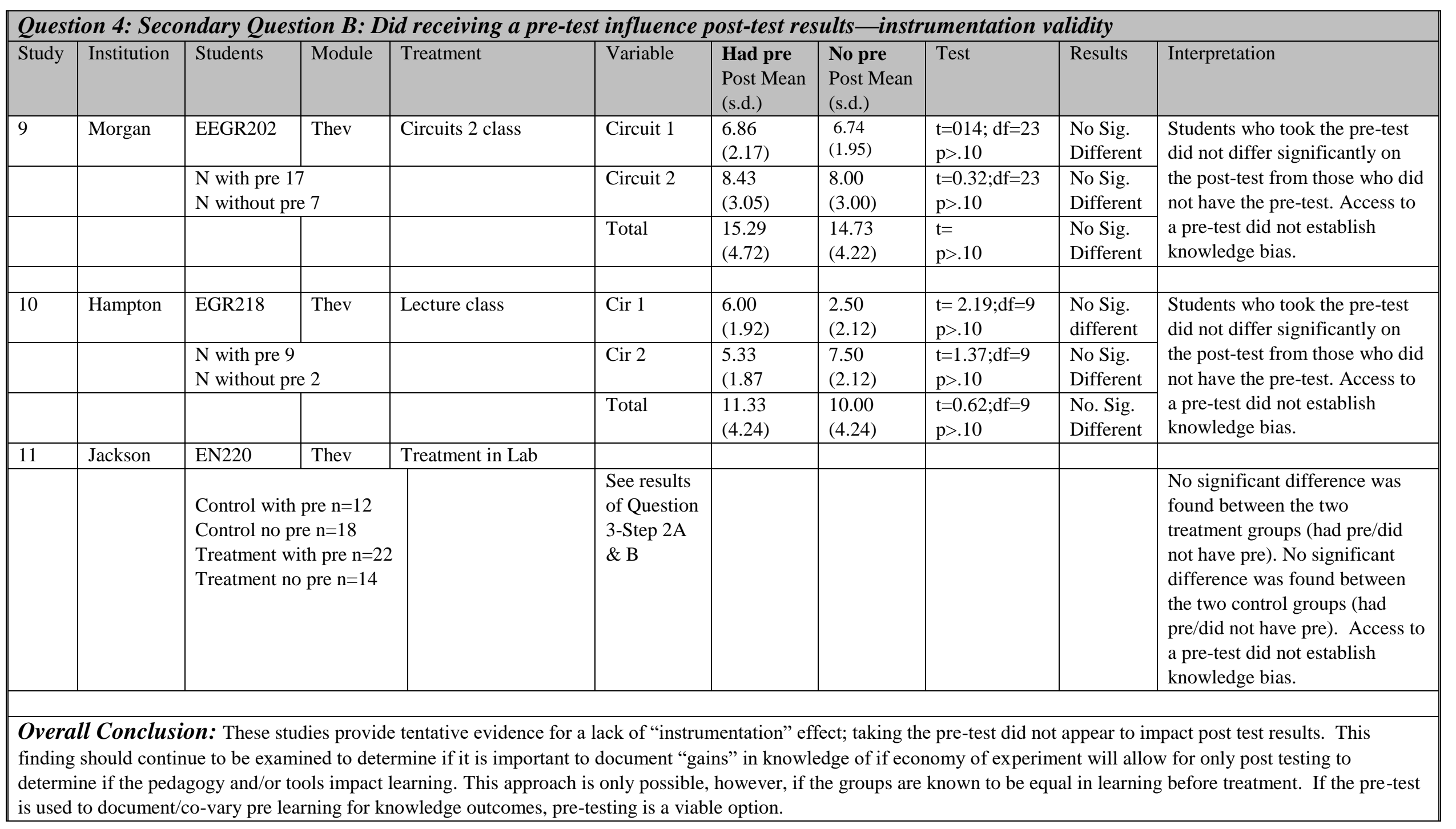




\section{Summary}

This paper summarizes the outcomes of a series of initial pilot studies investigating the impact of experiment centric learning supported by use of the analog discovery board. Three institutions conducted studies with students enrolled in introductory and circuit related engineering classes; two topics were addressed: Voltage Divider and Thevenin's Theorem. The settings included use in studio/integrated classes, labs, and homework supported activities. The instructors in treatment classes varied by experience, but all had at least three semesters of use. Two of the studies had control groups who did not receive use of the ADB.

Findings indicated that students in an introductory engineering class who received experiment centric pedagogy supported by the ADB made significantly greater gains than an equivalent group of students who received traditional instructional practices. The instructor in this setting was highly experienced in use of both the ECP and the ADB. The finding of this study, though limited to only one setting, supports continued documentation across different settings, instructors, and content.

In a second treatment/control study students who received experiment centric learning, supported by the ADB, as part of their required labs did not evidence significantly greater gains than did those students who did not receive the labs/treatment. Both sets of students received the same lecture coverage of the concepts; The treatment students, who were majors in EE started with more knowledge than the control students; both groups made gains in knowledge; Although gains were not significantly different, the gains for the treatment group were slightly higher than those of the control group. This finding supports the need for further studies across different majors and use in lab-separate instructional settings. Additional forms of calculating gain in knowledge other than raw gains should also be investigated.

Multiple studies, settings, and content evidenced gains in knowledge when students received experiment centric pedagogy supported by the ADB. Gains were made in both introductory engineering and circuit related classes for both major and non-major students. These findings support faculty and student self-reported knowledge gains documented in previous papers. The findings of these studies supported continued experimental use of the ADB with additional documentation of cognitive outcomes and project work.

Additional future experimental studies of ECP/ADB use will assist in broader generalization of findings and future implementation. Studies addressing mortality and subject differentiation (4A: Do students who "drop out" (don't take post-test) differ from those who complete the course) provided mixed evidence of mortality/drop-out/non-completer issues. Although the statistical tests are not significant, these findings may be related to sample size. Examination of the means indicate possible differences across sites/experiences that should be investigated further. Additional studies also should investigate if use of ECP/ADB decreases potential drop out. Tentative evidence for a lack of "instrumentation" effect (Question 4B); does the pre-test impact post test results). Tentative evidence indicates that access to the pre-test does not influence subsequent post test scores. This finding should continue to be examined to determine if it is important to document "gains" in knowledge of if economy of experiment will allow for only post testing to determine if the pedagogy and/or tools impact learning. This approach is only possible, however, if the groups are known to be equal in learning before treatment: if the pre- 
test is used to document/co-vary pre learning for knowledge outcomes and pre-testing is a viable option. Lack of instrumentation effect also indicates that the pre-test is not an active part of the "treatment".

These content related outcomes, when triangulated with the findings in Astatke (et. al) also indicate the potential for greater increases in content learning when experiment centric pedagogy is used with an integrated or studio pedagogy than in courses where theory and practice are separated. In Astatke (2016) a positive correlation was found between more integrated theory/practice classes and self-reported and faculty reported outcomes. Further research on the setting and instructional style are needed to address this issues.

Overall, the findings of these studies support hypotheses related to use of experiment centric instruction, hands-on learning, and use of mobile devices within engineering education. Across the studies, a positive trend is noted that for increased interest, increased immediate learning, and increased growth in learning when the ADB or similar mobile devices are used to support hands-on, real-world practice. These studies, while limited, indicated a need for further use of experiment centric learning supported by mobile simulated learning and the development of experimental studies that will document outcomes.

\section{References}

Streveler, R.A., Geist, M.R., Ammerman, R.F., Sulzbach, C.S., Miller, R.L., Olds, B.M, Nelson, M.A. (2006), "Identifying and Investigating Difficult Concepts in Engineering Mechanics and Electric Circuits," 2006 ASEE Annual Meeting, Chicago, paper 2006-1653

Astatke, Y, Connor, K.A., Newman, D. L, Attia, J.O. \& Nare, O. E. (2016), “ Growing experimental centric learning: the role of setting and instructional use in building student outcomes" 2016 ASEE Annual Meeting, New Orleans, paper ID\# 17030 
Appendix A

Pilot Circuits I Concepts Problems used at HBCU ECP partner institutions

Part II- Thevenin's Theorem

As part of efforts to evaluate Experimental Centric Based Engineering Curriculum for HBCUs, the Evaluation Consortium at the University at Albany/SUNY is collecting information from student participants. This information may be used to provide formative feedback to project staff, to document grant activities for the funder, and to aid in dissemination and knowledge development activities. Please read each of the following questions and provide the answer that reflects your status or opinion. Your participation is voluntary; your responses are strictly confidential and will not be released in any way that allows an individual to be identified. Only aggregate data will be presented in any reports. If you have any questions, please feel free to contact the Evaluation Consortium at the University at Albany/SUNY (518 442-5027 eval@albany.edu) or the University at Albany's Office of Regulatory Research Compliance (518 442-9050 orrc@albany.edu). Thank you for your participation.

Institution

Course

Semester

Date:

First Letter of Your Mother's First Name:

First Letter of Your Mother's Maiden Name:

Last Two Numbers of Student ID \#:

If you have a linear circuit, and you want to test it with a variable resistive load $\left(R_{L}\right)$, you can replace this circuit with a one that consists of a voltage source $\boldsymbol{V}_{\boldsymbol{T H}}$ in series with a resistor $\boldsymbol{R}_{\boldsymbol{T H}}$.

$\boldsymbol{V}_{\boldsymbol{T H}}$ is the voltage between A and B. The open circuit volt at the terminals.

$\boldsymbol{R}_{\boldsymbol{T H}}$ is resistance between $\mathrm{A}$ and $\mathrm{B}$.

To find $\boldsymbol{V}_{\boldsymbol{T H}} \rightarrow$ Calculate $\mathrm{V}$ between $\mathbf{A}$ and $\mathbf{B}$.

$$
\mathbf{v}_{\mathrm{TH}}=\mathbf{V}_{\mathrm{AB}}
$$

To find $\boldsymbol{R}_{\boldsymbol{T H}} \rightarrow$ Turn off all sources and calculate $\mathbf{R}$ between $\mathbf{A}$ and $\mathbf{B}$.

$$
\mathbf{R}_{\mathrm{TH}}=\mathbf{R}_{\mathrm{AB}}
$$

In the next two problems, you are to find the Thevenin voltage $V_{\mathrm{TH}}$ and resistance $\mathrm{R}_{\mathrm{TH}}$ for each circuit. 


\section{Circuit\#1:}

a) Keep the Source, Open $\mathrm{R}_{\mathrm{L}}$ and find $\mathrm{V}_{\mathbf{A B}}\left(\mathbf{V}_{\mathbf{T H}}\right)$

(4.5 points)

Note: students can use Nodal Analysis, Ohm's Law or Voltage Division to find $V_{T H}$

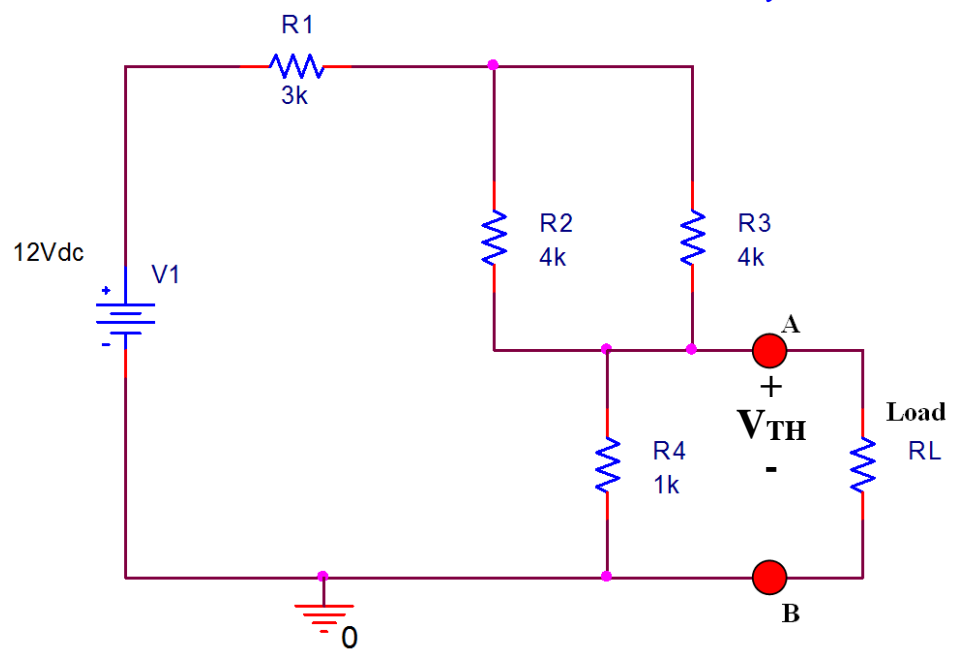

b) Short the Source, Open $R_{L}$ and find $\mathbf{R}_{\mathrm{AB}}\left(\mathbf{R}_{\mathrm{TH}}\right)$

(4.5 points)

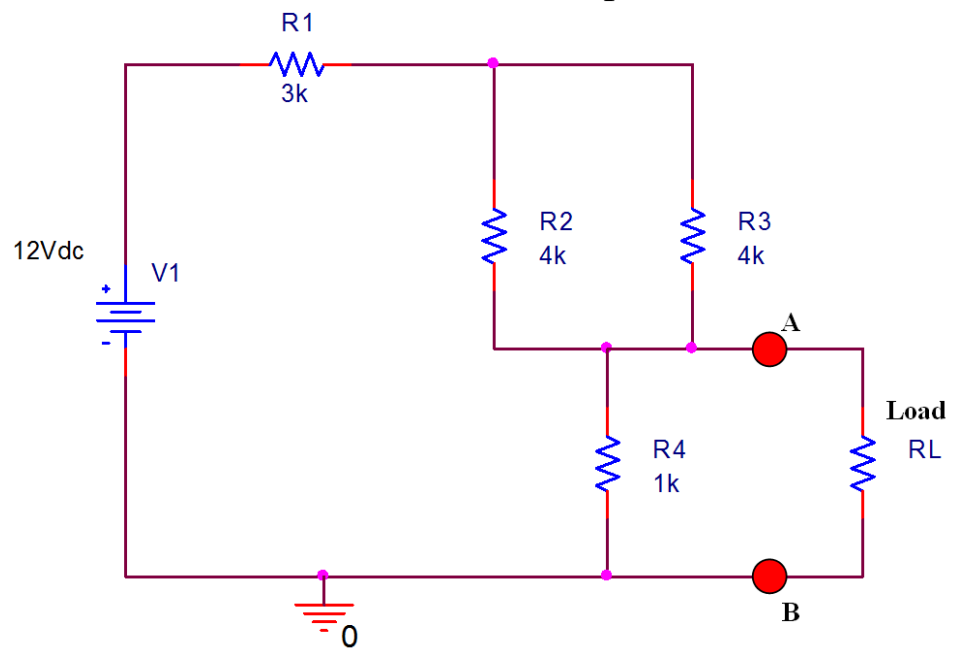

c) Draw the final Thevenin Circuit showing $\mathrm{V}_{\mathrm{TH}}$ and $\mathrm{R}_{\mathrm{TH}}$

(1 point)

Note: it is very important for students to draw the final Thevenin Circuit after they find $V_{T H}$ and $R_{T H}$ 


\section{Circuit\#2:}

a) Keep the Source, Open $\mathrm{R}_{\mathrm{L}}$ and find $\mathbf{V}_{\mathbf{A B}}\left(\mathbf{V}_{\mathbf{T H}}\right)$

(6 points)

Note: students can use Nodal Analysis, Ohm's Law or Voltage Division to find $V_{T H}$

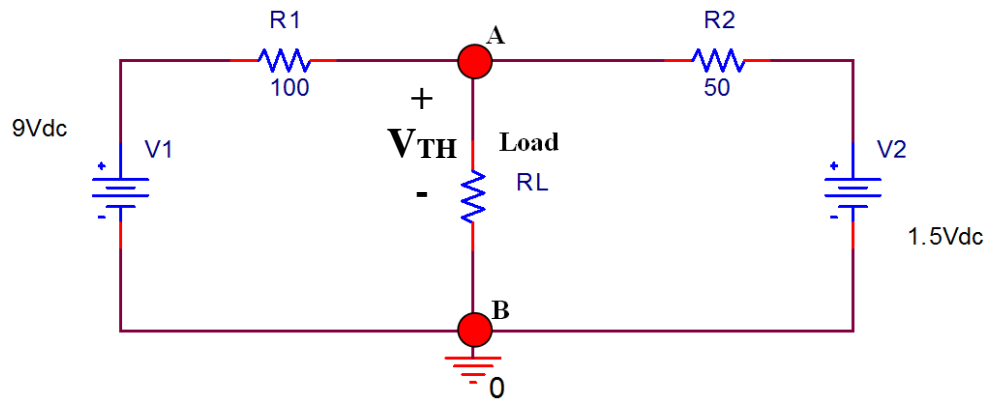

b) Short the Source, Open $R_{L}$ and find $\mathbf{R}_{\mathrm{AB}}\left(\mathbf{R}_{\mathrm{TH}}\right)$

(3 points)

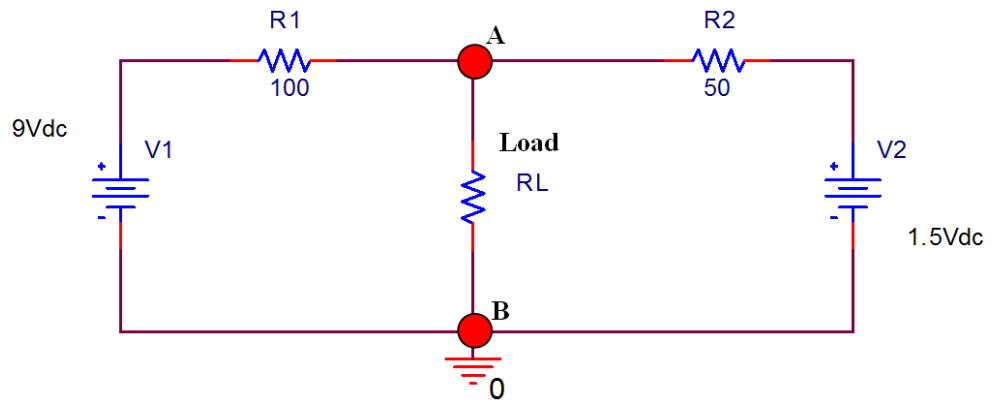

c) Draw the final Thevenin Circuit showing $\mathrm{V}_{\mathrm{TH}}$ and $\mathrm{R}_{\mathrm{TH}}$

(1 point)

Note: it is very important for students to draw the final Thevenin Circuit after they find $V_{T H}$ and $R_{T H}$ 


\section{Appendix B \\ In-Depth Presentation of Usage in Morgan State Introductory Class}

The experiment was conducted in two sections 3 and 4 (out of 4) of our "Introduction to Electrical Engineering" EEGR-105 freshmen level course. This a 3 credit second semester freshmen level course that is required for all ECE majors. It meets for two hours on Tuesdays and one hour on Thursdays. The first two sections of the EEGR 105 course cover concepts related to Matlab computation and programming (Module 1) while the other two sections (3, and 4) cover analog circuit theory concepts and laboratory instrumentation (Module 2). The students spend 7 weeks in each section learning either the concepts taught in Module 1 or 2 and switch to the second section after Mid-term exams to cover the other concepts. Typically, section 1 students switch courses with section 4 and section 2 students switch courses with section 3. This allows the ECE department to expose students enrolled in all 4 sections of EEGR 105 concepts that are covered in both modules 1 and 2 .

Sections 3 and 4 are conducted in classrooms that are equipped with about 10 laboratory benches that can be used to conduct regular laboratory experiments for courses such Electric Circuits, Electronics, etc. The instructors in both sections are required to cover introductory circuits theory such as series and parallel resistance combinations, Ohm's Law, and Kirchoff's voltage and current laws. The instructors also conduct hands on sessions using the regular laboratory instrumentation to teach students how to build circuits on breadboards and measure resistance, voltages and currents using the multimeters (Fig 2(a)). The students use the laboratory instruments in groups of 2 to 3 students. The main difference between how the hands-on sessions in the two sections are conducted is that the instructor in section 3 only used the regular laboratory equipment (labeled as control group), whereas the instructor in section 4 used the portable laboratory instrumentation (such as the Analog Discovery Board) inside and outside the classroom in addition to the regular laboratory equipment. Both types of laboratory instrumentation set-ups are shown in Figure 2. The experiments in both sections were conducted as follows. Both instructors in sections 3 and 4 covered the concepts related to Ohm's Law before the pre-test was given. At this stage, the students were given the pre-test and were asked the find the various voltages in the three circuits using Ohm's Law, and voltage division (concept that is not covered in class). Afterwards, both the instructors went ahead and covered the concept of voltage division in the class room and conducted laboratory experiments that reinforced both concepts. The instructor in section 4 then introduced the portable laboratory instrumentation to the students and allowed them to experiment with building and testing circuits that further enhanced the concept of ohm's law and voltage division both inside and outside the classroom. The students took the portable laboratory instrumentation at home and conducted hands-on experiments with their partners. The students enrolled in sections 3 and 4 were then given the post-test with the same type of circuits as the pre-test and were asked to compute voltages using both Ohms' Law and voltage division. The goal of the experiment was to find out whether there was any noticeable improvement in how the students enrolled in sections 3 and 4 performed on the post-test questions after two types of interventions were conducted. Students enrolled in section 3 were introduced to analog 
circuit theory and hands-on sessions using the conventional instrumentation. On the other hand, students enrolled in section 4 were exposed to a more engaging and immersive "Experiment centric Pedagogy" that closely combined both the theory and hands-on sessions using portable instrumentation inside and outside of the classroom.

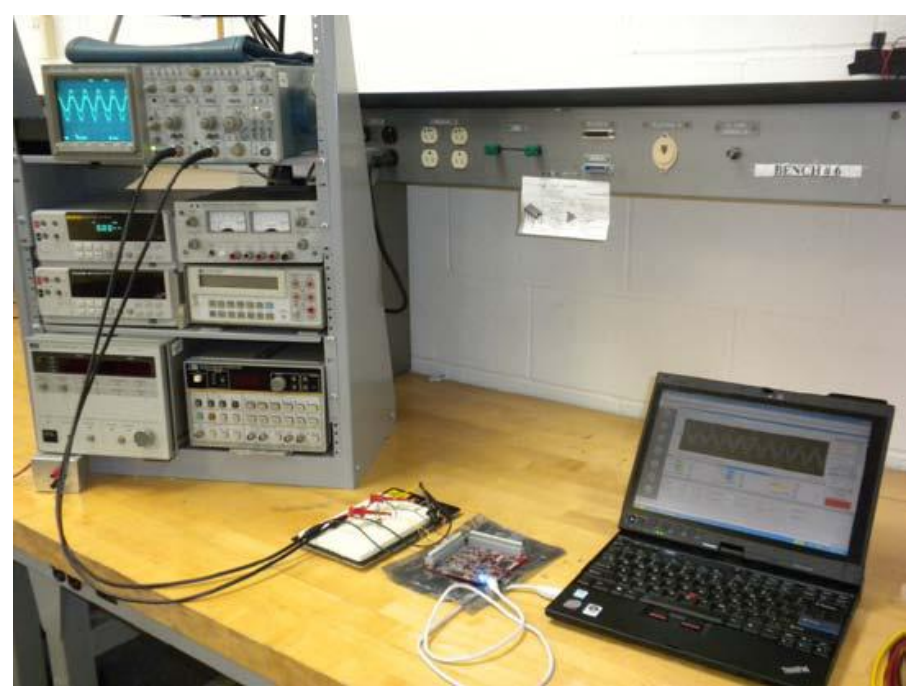

Figure 2: conventional laboratory bench (left side) and portable laboratory set-up with laptop (right side)

\author{
Appendix C \\ In-depth Presentation of Jackson State Usage
}

(See following pages) 


\section{Laboratory 8: Thevenin's and Norton's Theorems and Maximum Power Transfer}

LAB STUDENT:

LAB INSTRUCTOR:

DATE:

\section{OBJECTIVES}

1. Measure $\mathrm{V}_{\mathrm{TH}}$ (Thevenin's voltage) and $\mathrm{I}_{\mathrm{N}}$ (Norton's current)

2. Calculate $\mathrm{R}_{\mathrm{TH}}$ (Thevenin's and Norton's resistance) using 2 methods

3. Verify Source Transformation

4. Verify Thevenin's Theorem

5. Verify Maximum Power Transfer

\section{MINIMUM KNOWLEDGE}

Thevenin's and Norton's theorems, Maximum Power Transfer, and Source Transformation.

\section{EQUIPMENT REQUIRED}

1. Analog Parts Kit

2. Analog Discovery Board

3. Software: B2 Spice, Waveforms and MATLAB

\section{LAB WORK PROCEDURE}

\section{Calculations}

1. In the circuit shown, calculate the voltage across $R_{L}$.

$\mathrm{V}_{\mathrm{RL}}$ (in the original circuit $)=$

2. Find Thevenin's and Norton circuits between A and B.

3. For $\mathrm{V}_{\mathrm{TH}}$, disconnect $\mathrm{R}_{\mathrm{L}}$ and calculate the open circuit voltage between $\mathrm{A}$ and $\mathrm{B} . \quad \mathrm{V}_{\mathrm{TH}}=$

4. For $\mathrm{I}_{\mathrm{N}}$, replace $\mathrm{R}_{\mathrm{L}}$ by short circuit, then calculate the short

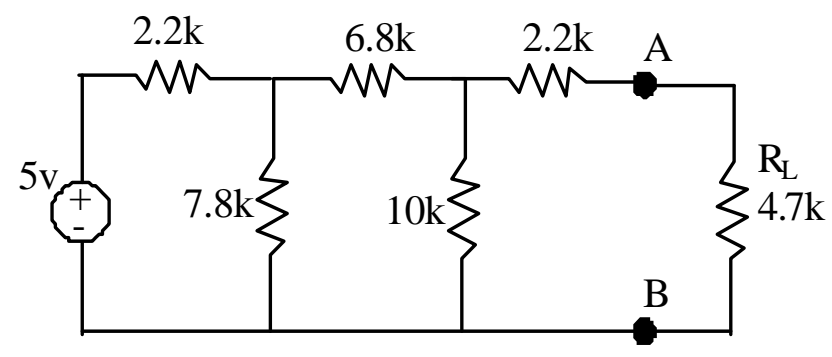

Fig. 1 circuit current from A to B. $\mathrm{I}_{\mathrm{N}}=$

5. For $\mathrm{R}_{\mathrm{TH}}$, turn off all sources and calculate the resistance between $\mathrm{A}$ and $\mathrm{B}$.

$\mathrm{R}_{\mathrm{TH}}=$

6. The Thevenin's and Norton Circuits will be as those shown below.

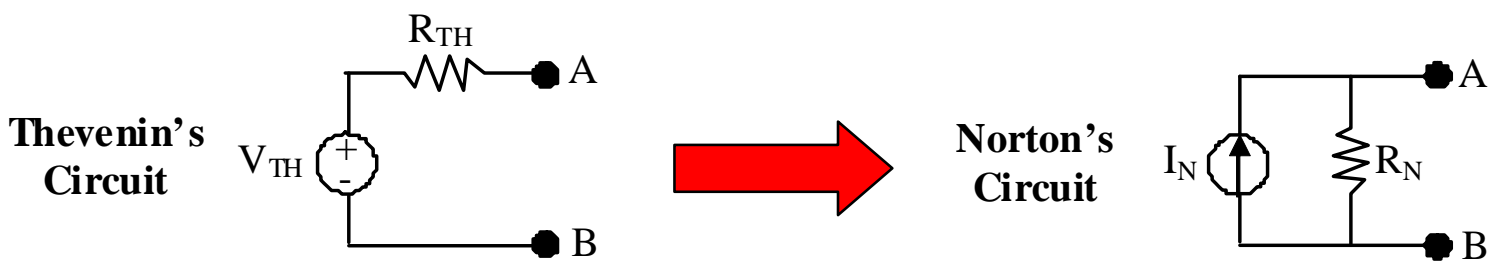


7. Norton's Circuit is a source transformation for Thevenin's one. According to source transformation $\mathrm{R}_{\mathrm{N}}$ is equal to $\mathrm{R}_{\mathrm{TH}}$, and $\mathrm{V}_{\mathrm{TH}}=\mathrm{I}_{\mathrm{N}} \times \mathrm{R}_{\mathrm{TH}}$, then $\mathrm{R}_{\mathrm{TH}}$ should be calculated as follow:

$R_{T H}=R_{N}=V_{T H} / I_{N}$.

Calculate $\mathrm{R}_{\mathrm{TH}}$ again using this method. $\quad \mathrm{R}_{\mathrm{TH}}=$

Compare the two results obtained for $\mathrm{R}_{\mathrm{TH}}$ in steps 5 and 7 . The results must be the same, and this verifies source transformation.

8. Connect $\mathrm{R}_{\mathrm{L}}$ (4.7k) to the Thevenin's Equivalent Circuit, and re-calculate the voltage.

$\mathrm{V}_{\mathrm{RL}}$ (in Thevenin's Equivalent Circuit) $=$

Compare this result with the one in step 3. They have to be equal (or very close), and this verifies Thevenin's Theorem.

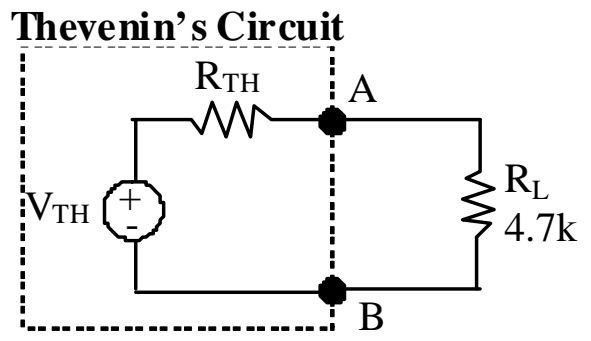

9. Connect $\mathrm{R}_{\mathrm{L}}(4.7 \mathrm{k})$ to the Norton Equivalent Circuit, and re-calculate the voltage.

$\mathrm{V}_{\mathrm{RL}}$ (in Norton's Equivalent Circuit) $=$

Compare this result with the one in step 3. They have to be equal (or very close), and this verifies Norton's Theorem.

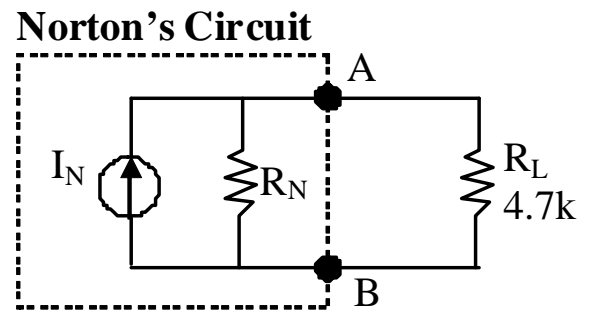

10. Connect different load resistors between $A$ and $B$ in the Thevenin's Circuit, and calculate the power delivered to the load.

$V_{L}=V_{T H} \frac{R_{L}}{R_{L}+R_{T H}}$, and $P_{L}=\frac{V_{L}^{2}}{R_{L}}$

Fill the following table.

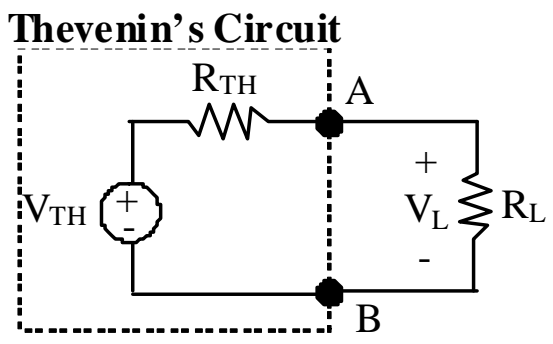

\begin{tabular}{|c|c|c|c|c|c|c|c|c|c|}
\hline $\mathrm{R}_{\mathrm{L}}$ & $2.2 \mathrm{k}$ & $3.2 \mathrm{k}$ & $4.7 \mathrm{k}$ & $5.6 \mathrm{k}$ & $6.8 \mathrm{k}$ & $8.3 \mathrm{k}$ & $10 \mathrm{k}$ & $12.2 \mathrm{k}$ & $14.7 \mathrm{k}$ \\
\hline $\mathrm{P}_{\mathrm{L}}$ & & & & & & & & & \\
\hline
\end{tabular}

What is the value of $\mathrm{R}_{\mathrm{L}}$ that achieves maximum power transfer?

$\mathrm{R}_{\mathrm{L}}($ Max Power $)=$

How does this resistance of maximum power compare to $\mathrm{R}_{\mathrm{TH}}$ ?

11. Use MATLAB to plot $R_{L}$ vs. $P_{L}$ using the results in the previous table. Open "m" file and write the code shown below. Run the file using "F5" to generate the figure shown below. 
ENL 220 CIRCUITS LAB
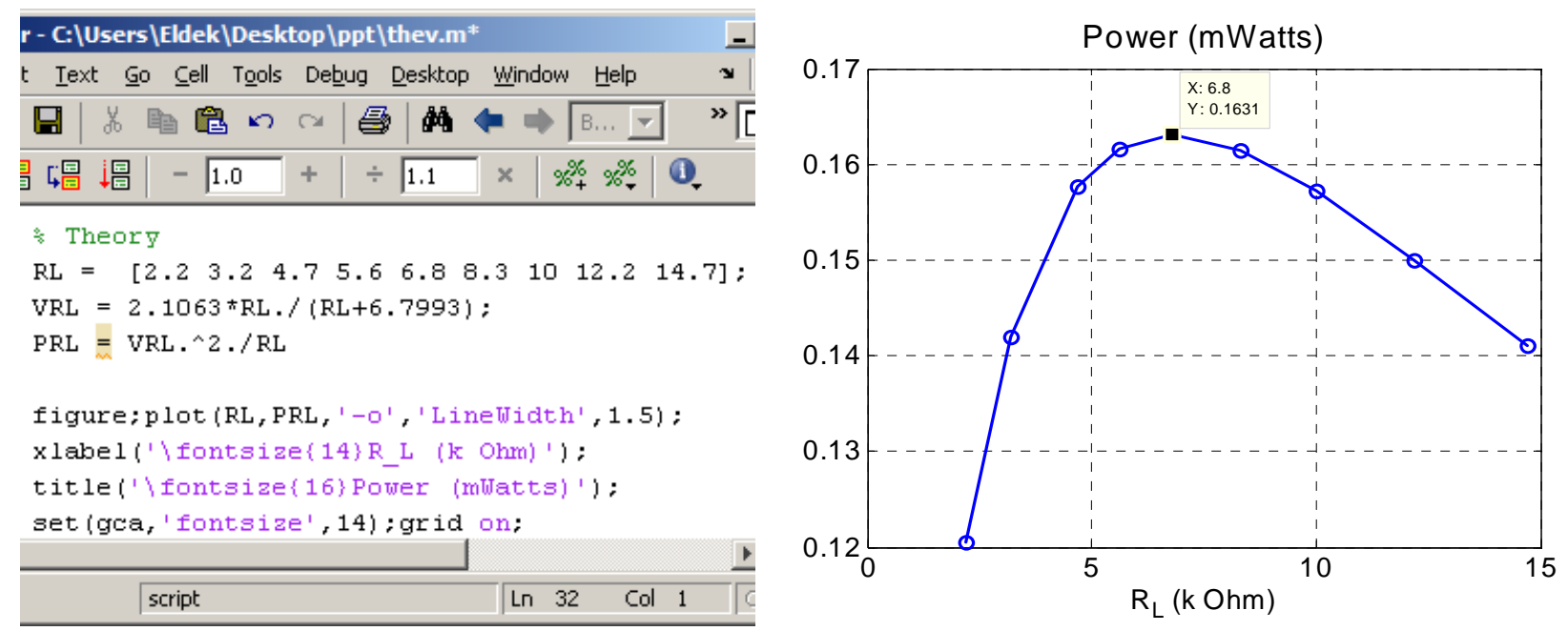

Add a marker at the top point of the curve. This is the point of the maximum power.

\section{$\underline{\text { B2Spice }}$}

12. Verify the calculated results using B2Spice.

13. In the circuit shown, use voltmeter to measure the voltage across $R_{L}$.

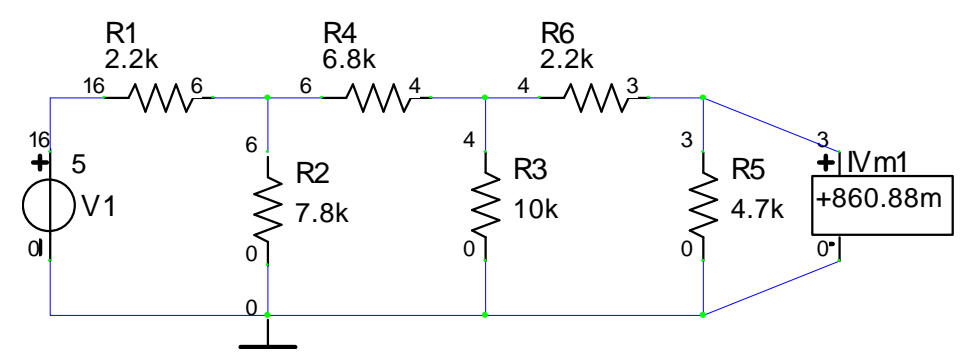

$\mathrm{V}_{\mathrm{RL}}=$

14. Find Thevenin's and Norton circuits between A and B.

15. For $\mathrm{V}_{\mathrm{TH}}$, disconnect $\mathrm{R}_{\mathrm{L}}$ and measure the open circuit voltage between $\mathrm{A}$ and $\mathrm{B}$.

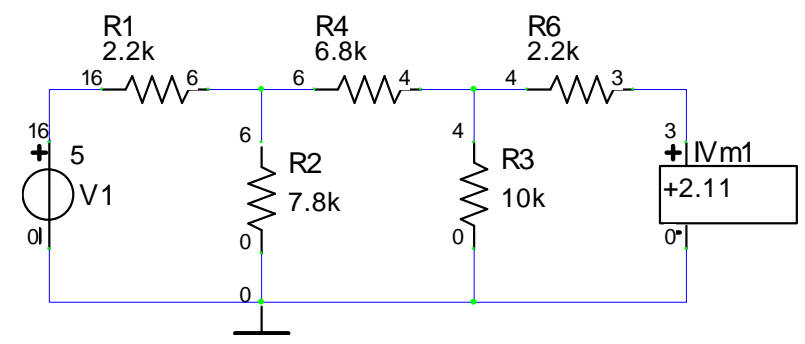

$$
\mathrm{V}_{\mathrm{TH}}=
$$

16. For $I_{N}$, replace $R_{L}$ by short circuit, then $I_{N}$ is the current in the short circuit from $A$ to $B$.

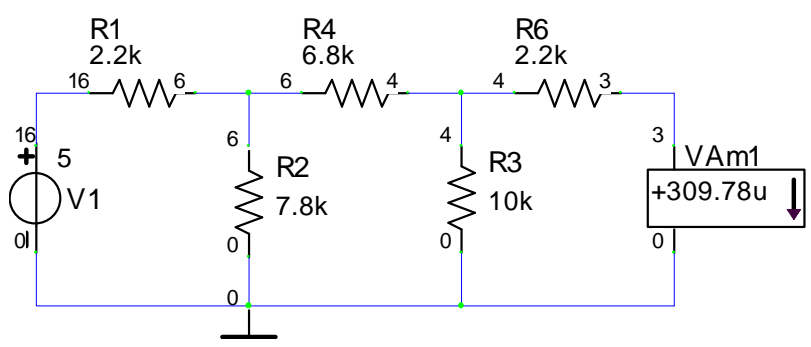

$$
\mathrm{I}_{\mathrm{N}}=
$$


17. For $\mathrm{R}_{\mathrm{TH}}$, turn off all sources, then connect Voltage Source between A and $\mathrm{B}$, and measure the input current from A to B. $R_{T H}=V_{1} / I_{-t o+}$.

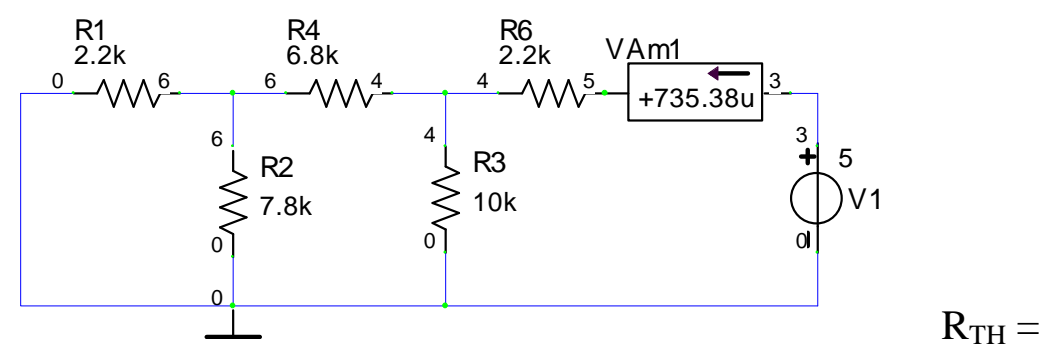

18. The Thevenin's and Norton Circuits will be as those shown below.
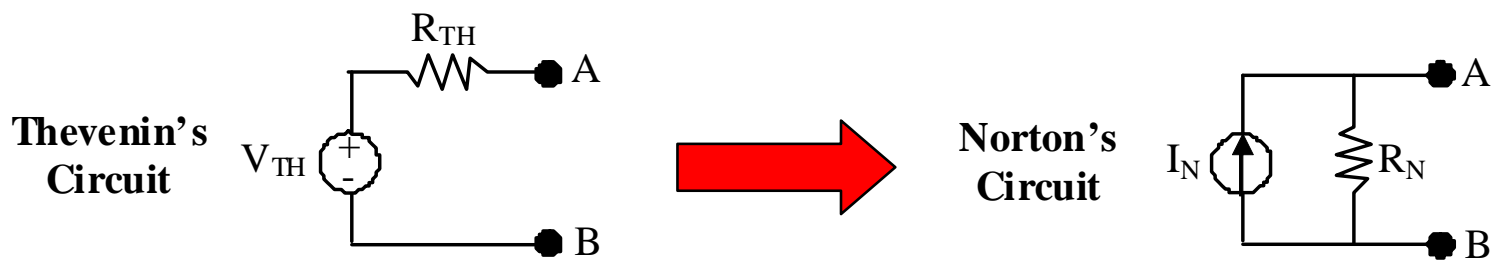

19. Norton's Circuit is a source transformation for Thevenin's one. According to source transformation $\mathrm{R}_{\mathrm{N}}$ is equal to $\mathrm{R}_{\mathrm{TH}}$, and $\mathrm{V}_{\mathrm{TH}}=\mathrm{I}_{\mathrm{N}} \times \mathrm{R}_{\mathrm{TH}}$, then $\mathrm{R}_{\mathrm{TH}}$ should be calculated as follow: $R_{T H}=R_{N}=V_{T H} / I_{N}$.

Calculate $\mathrm{R}_{\mathrm{TH}}$ again using this method. $\quad \mathrm{R}_{\mathrm{TH}}=$

Compare the two results obtained for $\mathrm{R}_{\mathrm{TH}}$ in steps 17 and 19. The results must be the same, and this verifies source transformation. However, small differences may result because the multimeter rounds the results.

20. Connect $R_{L}(4.7 k)$ to the Thevenin's Equivalent Circuit, and re-measure the voltage.

\section{Thevenin's Circuit}

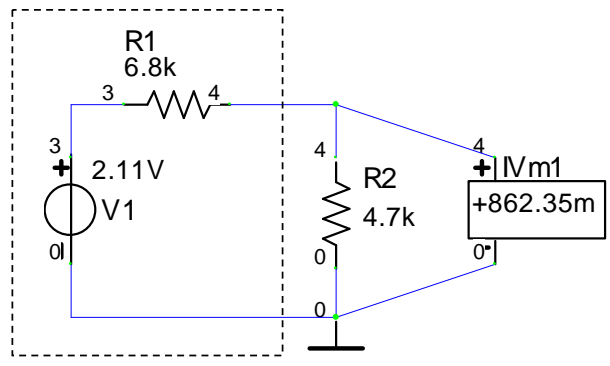

$\mathrm{V}_{\mathrm{RL}}$ (in Thevenin's Equivalent Circuit) $=$

Compare this result with the one in step 13. They have to be equal (or very close), and this verifies Thevenin's Theorem.

21. Connect $\mathrm{R}_{\mathrm{L}}(4.7 \mathrm{k})$ to the Norton Equivalent Circuit, and re-calculate the voltage.

$\mathrm{V}_{\mathrm{RL}}$ (in Norton's Equivalent Circuit) = 
Compare this result with the one in step 13. They have to be equal (or very close), and this verifies Norton's Theorem.

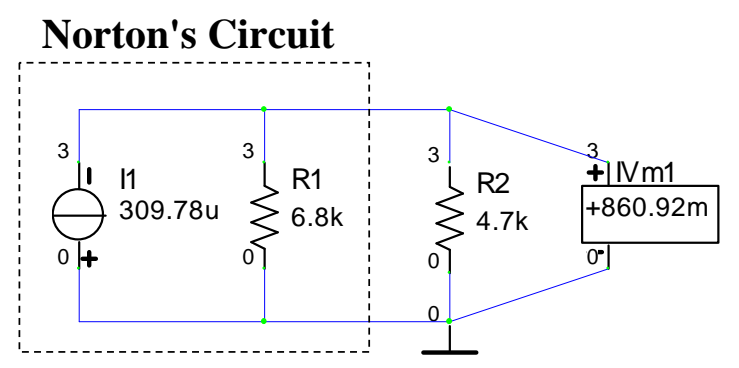

22. Connect different load resistors between A and B in the Thevenin's Circuit (in the previous step), and measure the load Voltage $\left(\mathrm{V}_{\mathrm{L}}\right)$, then calculate the power delivered to the load $\left(\mathrm{P}_{\mathrm{L}}\right)$.

$$
P_{L}=\frac{V_{L}^{2}}{R_{L}} .
$$

Fill the following table.

\begin{tabular}{|c|c|c|c|c|c|c|c|c|c|}
\hline $\mathrm{R}_{\mathrm{L}}$ & $2.2 \mathrm{k}$ & $3.2 \mathrm{k}$ & $4.7 \mathrm{k}$ & $5.6 \mathrm{k}$ & $6.8 \mathrm{k}$ & $8.3 \mathrm{k}$ & $10 \mathrm{k}$ & $12.2 \mathrm{k}$ & $14.7 \mathrm{k}$ \\
\hline $\mathrm{P}_{\mathrm{L}}$ & & & & & & & & & \\
\hline
\end{tabular}

What is the value of $\mathrm{R}_{\mathrm{L}}$ that achieves maximum power transfer?

$\mathrm{R}_{\mathrm{L}}($ Max Power $)=$

How does this resistance of maximum power compare to $\mathrm{R}_{\mathrm{TH}}$ ?

23. Use MATLAB to plot $R_{L}$ vs. $P_{L}$ using the results in the previous table. Open "m" file and write the code shown below. Run the file using "F5" to generate the figure shown below.
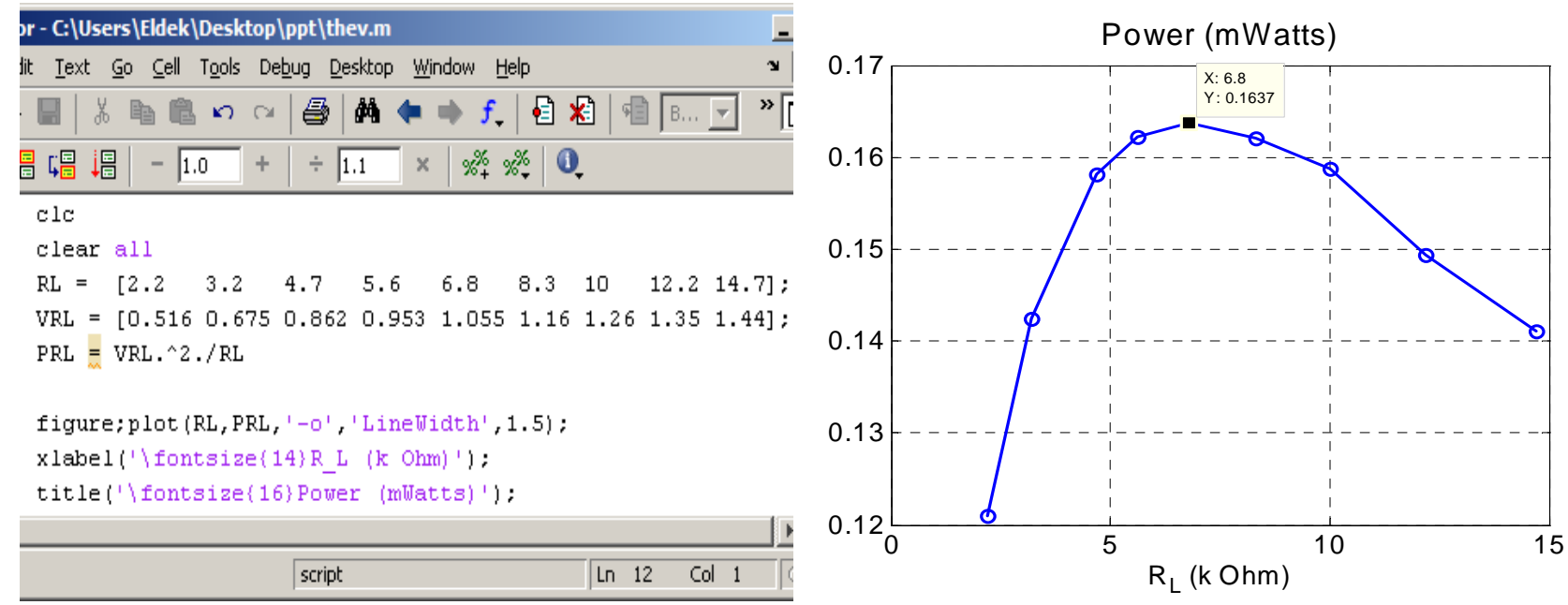

Add a marker at the top point of the curve. This is the point of the maximum power. 


\section{$\underline{\text { Analog Discovery and Waveforms }}$}

24. Breadboard the circuit in Fig. 1.

25. Use the voltmeter of Analog Discovery to measure the voltage across $\mathrm{R}_{\mathrm{L}}$ in the complete circuit.

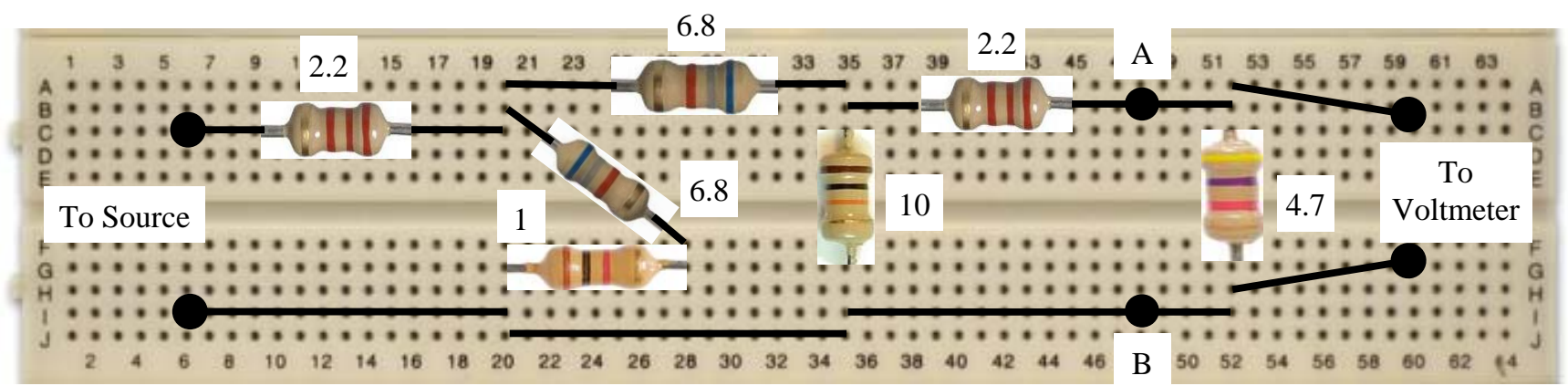

$\mathrm{V}_{\mathrm{RL}}($ Comlete Circuit $)=$

26. Find Thevenin's and Norton circuits between A and B.

27. For $\mathrm{V}_{\mathrm{TH}}$, disconnect $\mathrm{R}_{\mathrm{L}}$ and measure the open circuit voltage between $\mathrm{A}$ and $\mathrm{B}$.

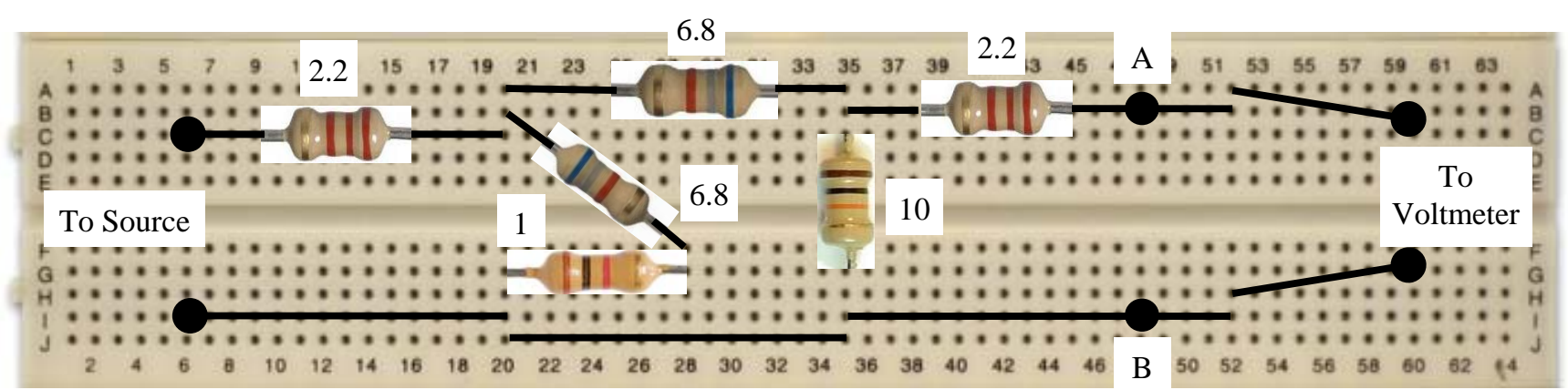

$\mathrm{V}_{\mathrm{TH}}=$

28. For $I_{N}$, replace $R_{L}$ by short circuit, then $I_{N}$ is the current in the short circuit from $A$ to $B$. Since Analog Discovery measures voltage only, and the short circuit current is the same as the $2.2 \mathrm{k}$ current (the right one), measure the voltage across this $2.2 \mathrm{k}$, and use Ohm's law to calculate its current.

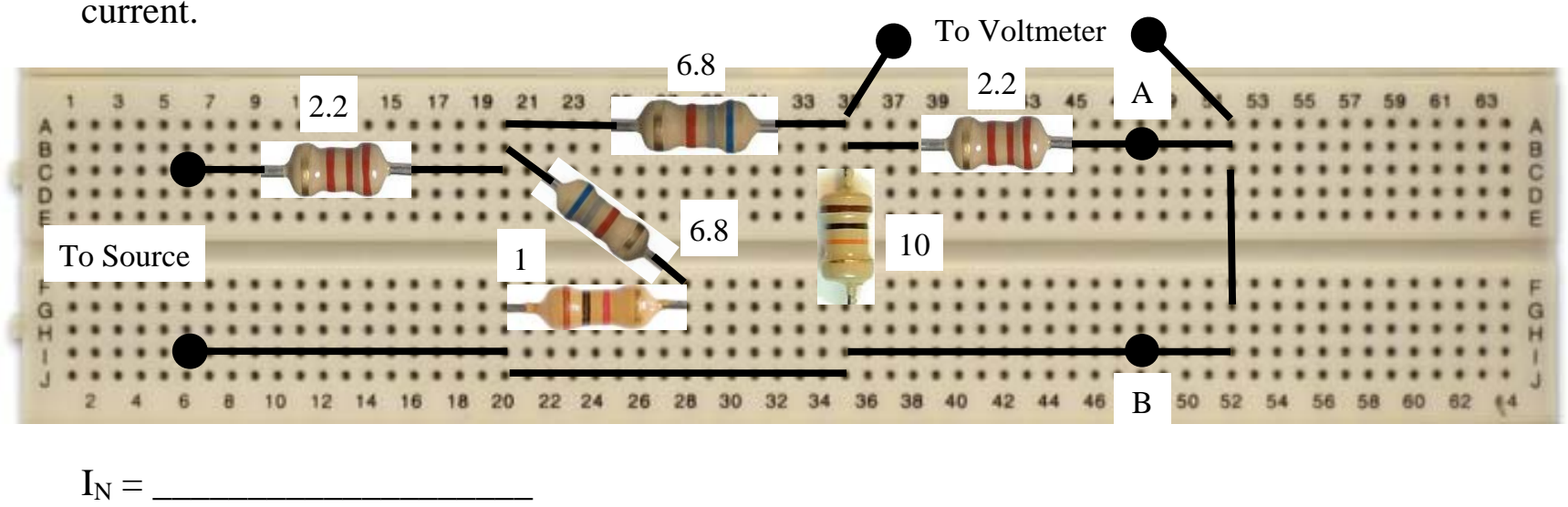


29. For $\mathrm{R}_{\mathrm{TH}}$, replace the voltage source by short circuit, then connect the voltage source between $\mathrm{A}$ and $\mathrm{B}$, and calculate the input current from A to B (from the - to + in the source). This current is the same in the $2.2 \mathrm{k}$ (the right one), but in the opposite direction of the one in Step 28. Measure the voltage across this resistor and calculate the current using Ohm's law. Finally, the thevenin's resistance equals the voltage of the source divided by that current. $R_{T H}=V_{1} / I_{-t_{+}+}$.

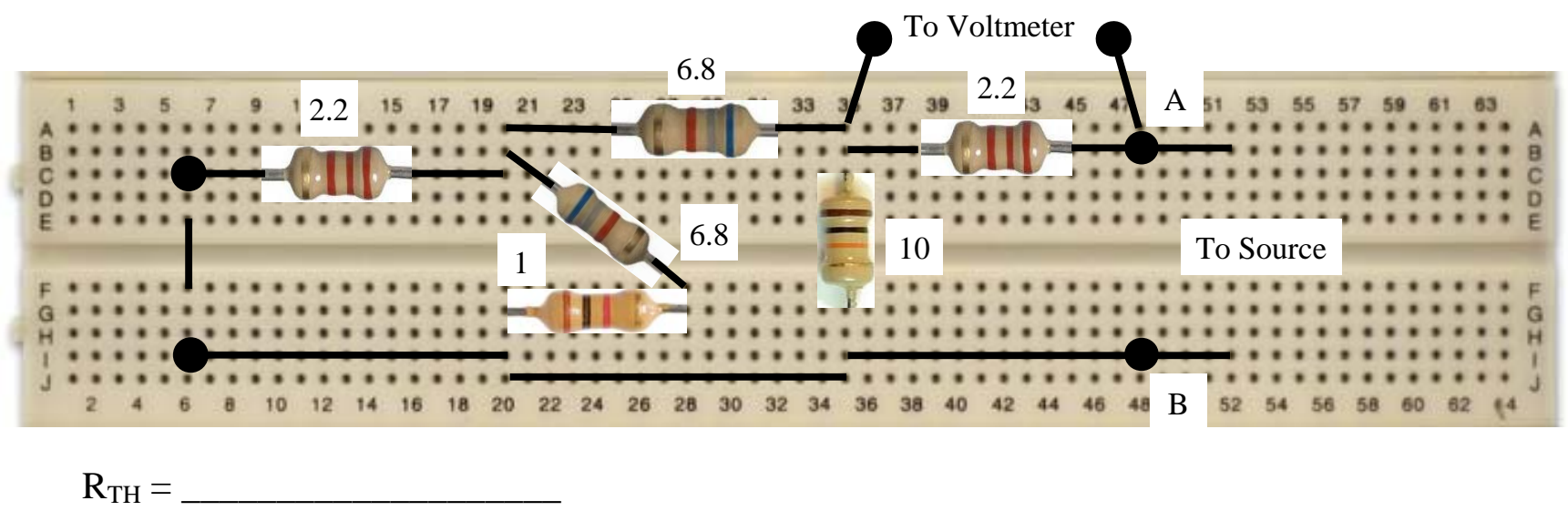

30. The Thevenin's and Norton Circuits will be as those shown below.
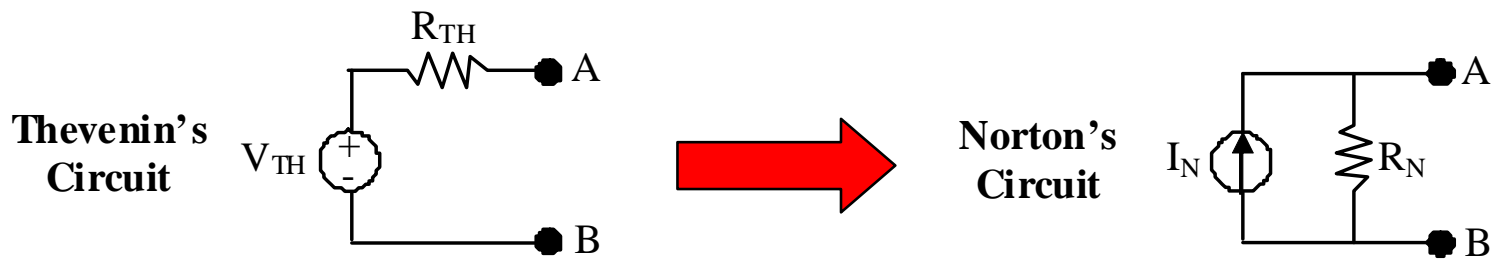

31. Norton's Circuit is a source transformation for Thevenin's one. According to source transformation $\mathrm{R}_{\mathrm{N}}$ is equal to $\mathrm{R}_{\mathrm{TH}}$, and $\mathrm{V}_{\mathrm{TH}}=\mathrm{I}_{\mathrm{N}} \times \mathrm{R}_{\mathrm{TH}}$, then $\mathrm{R}_{\mathrm{TH}}$ should be calculated as follow:

$$
R_{T H}=R_{N}=V_{T H} / I_{N} \text {. }
$$

Calculate $\mathrm{R}_{\mathrm{TH}}$ again using this method. $\quad \mathrm{R}_{\mathrm{TH}}=$

Compare the two results obtained for $\mathrm{R}_{\mathrm{TH}}$ in steps 29 and 31. The results must be the same, and this verifies source transformation. However, small differences may result because the multimeter rounds the results.

32. Connect $\mathrm{R}_{\mathrm{L}}(4.7 \mathrm{k})$ to the Thevenin's Equivalent Circuit, and re-measure the voltage.

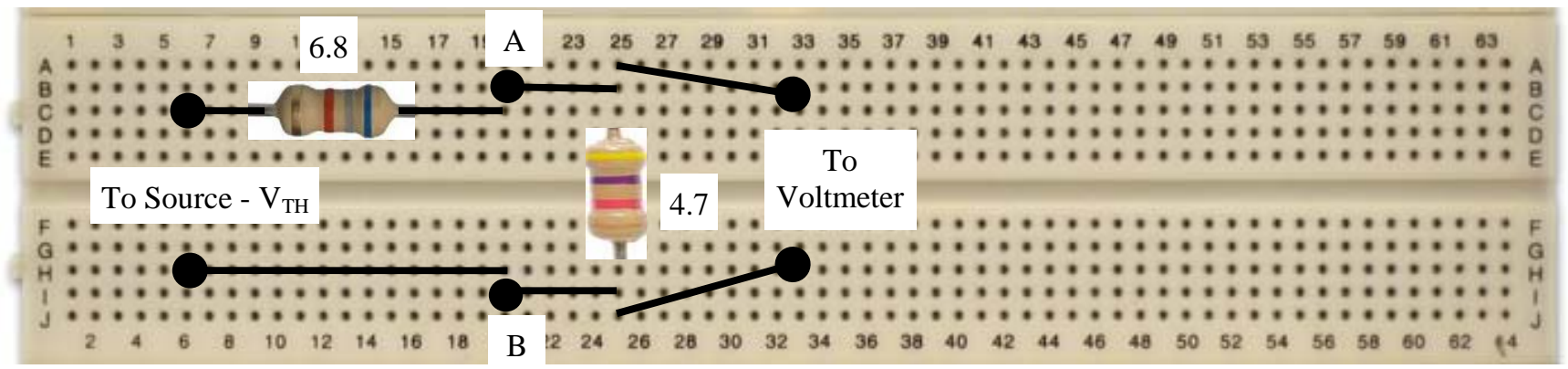


$\mathrm{V}_{\mathrm{RL}}$ (in Thevenin's Equivalent Circuit) $=$

Compare this result with the one in step 25. They have to be equal (or very close), and this verifies Thevenin's Theorem.

33. Connect different load resistors between A and B in the Thevenin's Circuit (in the previous step), and measure the load Voltage $\left(\mathrm{V}_{\mathrm{L}}\right)$, then calculate the power delivered to the load $\left(\mathrm{P}_{\mathrm{L}}\right)$.

$$
P_{L}=\frac{V_{L}^{2}}{R_{L}} .
$$

Fill the following table.

\begin{tabular}{|c|c|c|c|c|c|c|c|c|c|}
\hline $\mathrm{R}_{\mathrm{L}}$ & $2.2 \mathrm{k}$ & $3.2 \mathrm{k}$ & $4.7 \mathrm{k}$ & $5.6 \mathrm{k}$ & $6.8 \mathrm{k}$ & $8.3 \mathrm{k}$ & $10 \mathrm{k}$ & $12.2 \mathrm{k}$ & $14.7 \mathrm{k}$ \\
\hline $\mathrm{P}_{\mathrm{L}}$ & & & & & & & & & \\
\hline
\end{tabular}

What is the value of $\mathrm{R}_{\mathrm{L}}$ that achieves maximum power transfer?

$\mathrm{R}_{\mathrm{L}}($ Max Power $)=$

How does this resistance of maximum power compare to $\mathrm{R}_{\mathrm{TH}}$ ?

34. Use MATLAB to plot $R_{L}$ vs. $P_{L}$ using the results in the previous table. Open "m" file and write the code shown below. Run the file using "F5" to generate the figure shown below.
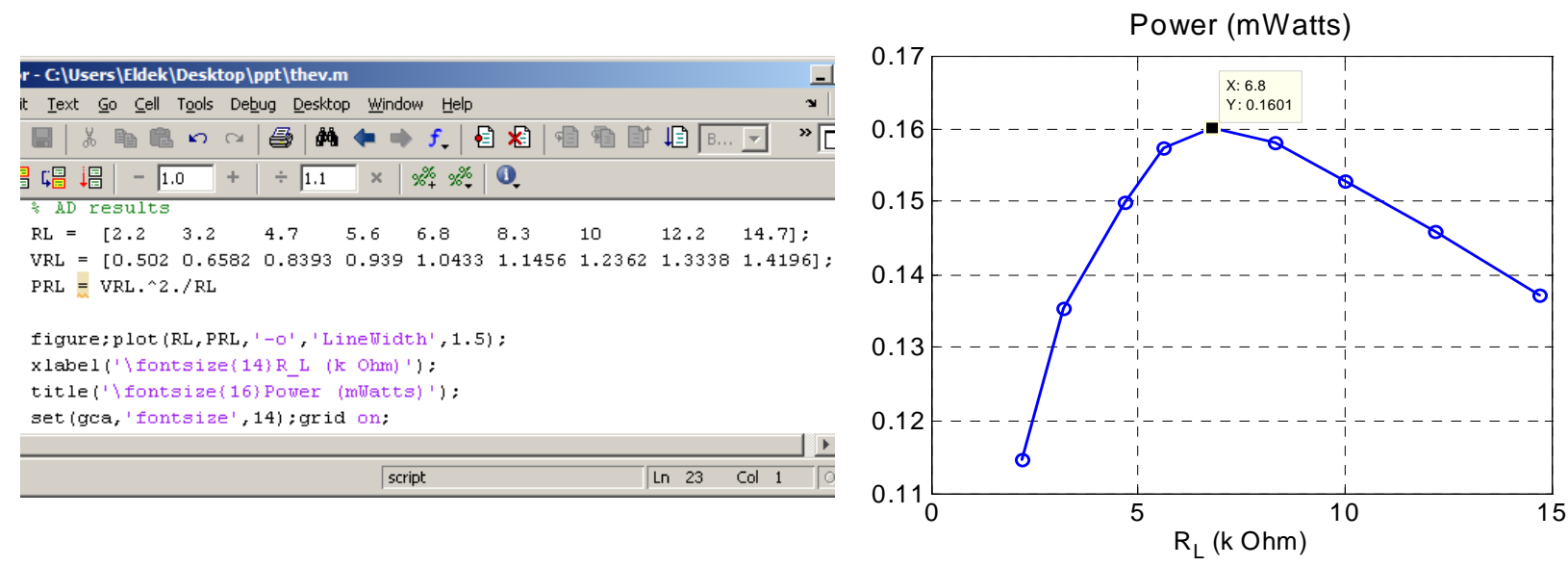

Add a marker at the top point of the curve. This is the point of the maximum power.

35. In order to compare the results from Calculations, B2Spice, and Analog Discovery, use MATLAB to plot the three $\mathrm{R}_{\mathrm{L}}$ vs. $\mathrm{P}_{\mathrm{L}}$ curves on each other. Open "m" file and write the code shown below. Run the file using "F5" to generate the figure shown below. 
ENL 220 CIRCUITS LAB

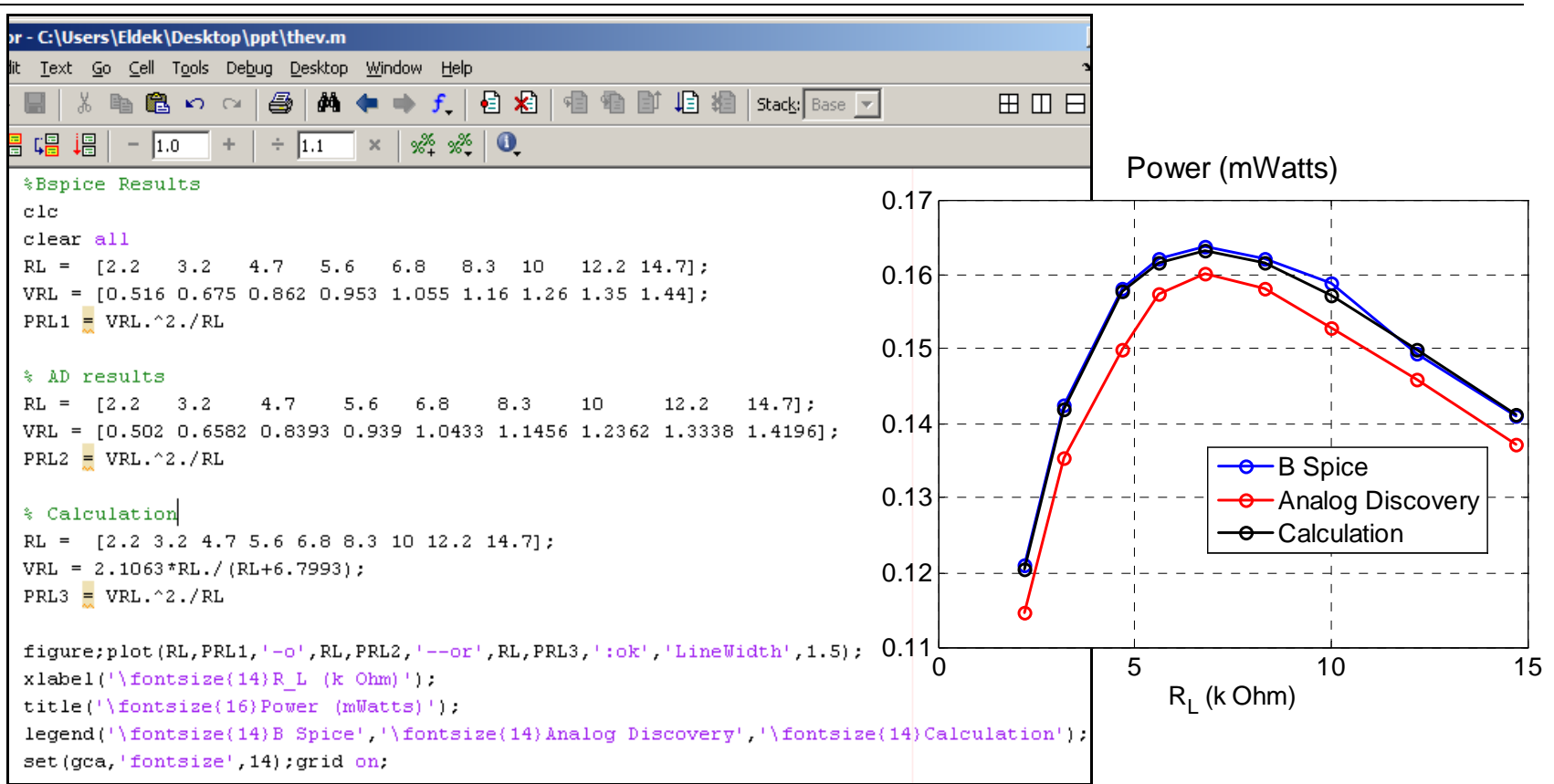

\section{POST-LAB WORK}

The student is required to write a formal report on this experiment. The Report is due within $\mathbf{2}$ weeks. The report must have the following:

a. Cover page including Experiment Title, Student name, Class Name, Professor Name and Date of the Experiment.

b. Table of Content Page (Topic and page number)

c. The Objectives of the Experiment

d. The Equipment/Software Used

e. Explanation of OpAmp operation

f. The Steps of the Experiment with all Results

g. Conclusions 